\title{
Aptidão da Bacia Hidrográfica do Rio Almada diante da implantação de áreas para disposição ambiental de rejeitos
}

\author{
The waste disposal suitability of Almada River Watershed
}

Ronaldo Lima Gomes ${ }^{1}$, Eduardo Antonio Gomes Marques², Gustavo Barreto Franco ${ }^{3}$

\begin{abstract}
RESUMO
Este trabalho objetivou identificar a adequabilidade da Bacia Hidrográfica do Rio Almada (BHRA) diante da implantação de áreas para a disposição de rejeitos por intermédio do reconhecimento das características dos atributos do meio físico e de uso e ocupação do solo. A metodologia adotada teve, inicialmente, as suas atividades associadas ao levantamento dos estudos ambientais e à consolidação dos mapeamentos temáticos já realizados na área da BHRA. Em seguida, os planos de informações temáticas, a exemplo de substrato rochoso, solos e formas de relevo, tiveram as suas características enquadradas em classes de adequabilidade à implantação de rejeitos de acordo com a proposta de Zuquette. Os resultados encontrados atestam o cenário em que a área da BHRA apresenta mais concentração de adequabilidades severas e restritivas localizadas nas porções oeste, norte e leste, em virtude da extensa ocorrência de áreas de preservação permanente (APPs) associadas às áreas de declividade superior a $45^{\circ} \mathrm{e}$ em porções de topo de morros, além da presença marcante de bolsões de floresta densa.
\end{abstract}

Palavras-chave: mapeamento geotécnico; fragilidades ambientais; disposição de rejeitos; Bacia do Rio Almada.

\begin{abstract}
This work had the objective to identify the suitability of the Almada River Watershed (ARW) front of the deployment areas for waste disposal from the recognition of physical environment and land use occupation characteristics. The methodology had initially its activities associated with the survey of environmental studies and consolidation of thematic maps already made in the ARW area. Then the plans of thematic information, like bedrock, soils and landforms, had its features framed in suitability classes to the implementation of waste disposal in accordance with the proposal of Zuquette. The results attested to the scenario in which the area of ARW has a higher concentration of severe and restrictive suitability located in the west, north and east portions, due to the extensive occurrence of permanent preservation areas in upper 450 slope areas and top portions of hills, associated with the presence of dense forest.
\end{abstract}

Keywords: engineering geological maps; environmental fragilities; waste disposal; Almada River Watershed.

\section{INTRODUÇÃO}

Atualmente, em todo o mundo, é discutida a temática da gestão de resíduos, fruto dos abrangentes problemas ambientais causados pela expansão das áreas urbanizadas e pela prática de consumo baseada na rápida substituição de bens, o que, por sua vez, reflete no aumento do descarte de embalagens e no acúmulo de imensa quantidade de resíduos (PROSKE et al., 2005). No Brasil, país de economia emergente, não é diferente. O crescente processo de urbanização e industrialização, aliado às práticas exageradas de consumo, tornam-no um dos maiores produtores de resíduos sólidos do mundo.
Nesse contexto, tendo em vista o enfrentamento de problemas ambientais, sociais e econômicos decorrentes do manejo inadequado dos resíduos sólidos no Brasil e a necessidade de execução de ações de redução na geração de resíduos e prática de destinação ambientalmente adequada dos rejeitos, foi instituída, em 2010, a Política Nacional de Resíduos Sólidos (PNRS) (BRASIL, 2010).

De acordo com a PNRS, mais precisamente o artigo $4 .^{\circ}$, na gestão e no gerenciamento de resíduos sólidos deve ser observada a seguinte ordem de prioridade: não geração, redução, reutilização, reciclagem, tratamento dos resíduos sólidos e disposição final ambientalmente adequada

\footnotetext{
'Professor Pleno do Departamento de Ciências Agrárias e Ambientais da Universidade Estadual de Santa Cruz (UESC) - Ilhéus (BA), Brasil. ${ }^{2}$ Professor Titular do Departamento de Engenharia Civil da Universidade Federal de Viçosa (UFV) - Viçosa (MG), Brasil. ${ }^{3}$ Professor Assistente do Departamento de Geografia da Universidade do Estado da Bahia (UNEB) - Salvador (BA), Brasil. Endereço para correspondência: Ronaldo Lima Gomes - Universidade Estadual de Santa Cruz, Campus Soane Nazaré de Andrade - Rodovia Jorge Amado, Km 16 Salobrinho - 45662-900 - Ilhéus (BA), Brasil - E-mail: rlgomes@uesc.br

Recebido: 12/08/15 - Aceito: 08/09/16 - Reg. ABES: 157490
} 
dos rejeitos. No que se refere à disposição adequada de rejeitos, foco deste trabalho, a PNRS descreve que a disposição sob a forma de aterro sanitário somente se dará quando não ocorrer possibilidade de reutilização, reciclagem ou tratamento daquele resíduo, que, nessa circunstância, se torna rejeito. Sendo assim, a PNRS prevê (artigo 17, inciso XI), "em conformidade com os demais instrumentos de planejamento territorial", a aplicação de métodos para a identificação de "zonas favoráveis para a localização de unidades de tratamento de resíduos sólidos ou de disposição final de rejeitos", bem como a necessidade de identificação de "áreas degradadas em razão de disposição inadequada de resíduos sólidos ou rejeitos a serem objeto de recuperação ambiental" (BRASIL, 2010).

De forma geral, a tecnologia utilizada em aterros sanitários baseia-se no gerenciamento do rejeito no sentido de controlar a migração de gases e efluentes gerados pela decomposição da matéria orgânica contida e de evitar o seu contato com águas de precipitação e subterrâneas. Tais ações evitam emissões atmosféricas de gases de efeito estufa e lixiviação de contaminantes que podem afetar a qualidade ambiental dos recursos hídricos. Logo, na escolha de áreas para execução de aterros sanitários, torna-se premissa fundamental o entendimento dos diferentes arranjos dos atributos do meio físico-ambiental que se relacionam, de maneira direta ou não, na dinâmica dos processos ocorrentes associados à implantação desse tipo de empreendimento.

Nesse cenário, no Brasil, a utilização de técnicas de mapeamento geotécnico que possuem como base o conhecimento da distribuição espacial de dados e atributos do meio físico destaca-se como importante ferramenta para o entendimento das potencialidades e limitações do terreno para determinada finalidade de uso. Em Zuquette e Gandolfi (1987), por exemplo, os atributos de declividade do terreno, a profundidade do substrato rochoso, a profundidade do nível de água subterrâneo, além de textura, capacidade de troca catiônica, pH e permeabilidade dos materiais não consolidados, são analisados para orientar a localização de fossas, lagoas de estabilização e aterros sanitários, fruto dos diversos procedimentos metodológicos para a execução de mapeamento geotécnico definidos em Zuquette (1987). Posteriormente, o referido autor revisou e consolidou os atributos estudados apresentando-os em Zuquette (1993), Zuquette, Pejon e Sinelli (1994) e Zuquette e Gandolfi (2004).

Nessa mesma época, Cunha e Parzanese (1993) apresentaram uma proposta metodológica para a seleção de locais adequados para a instalação de aterros industriais, baseados no conhecimento de informações hidrogeológicas, geotécnicas e de uso e ocupação. Além das necessárias e tradicionais informações geotécnicas e de comportamento da água no substrato, este trabalho destaca-se em virtude da utilização de atributos de uso e ocupação do solo, a exemplo da densidade habitacional da área, da distância de núcleos populacionais, da valorização da terra e dos zoneamentos ambientais.
Brollo et al. (1998) e Araújo et al. (1999) trazem propostas metodológicas para identificação de áreas potenciais destinadas à disposição de resíduos na Região Metropolitana de Campinas e no município de Americana, ambos em São Paulo, sendo consideradas na análise as características geotécnicas, climáticas, de uso e ocupação do solo e de legislação. Em Muro (2000), também utilizando técnicas de mapeamento geotécnico, é discutida a Carta de Zoneamento para Seleção de Áreas diante da Instalação de Aterros Sanitários no município de São Carlos, São Paulo, na escala 1:50.000. Basílio, Gandolfi e Zuquette (2001), por sua vez, aplicaram procedimentos para a hierarquização de áreas para implantação de aterros sanitários na região de Campinas, São Paulo. Esse trabalho considera cinco níveis de documentos cartográficos elaborados pela combinação de diversos atributos em conformidade com as propostas metodológicas de Zuquette (1993).

Métodos de análise multicritério e aplicação de lógica fuzzy foram utilizados por Calijuri, Melo e Lorentz (2002), tendo em vista a seleção de áreas para implantação de aterros sanitários. Nessa mesma linha, Marques e Zuquette (2004) aplicaram a técnica analytic hierarchy process (AHP) para seleção de áreas para aterros sanitários na região de Araraquara, São Paulo.

No Norte do país, o trabalho de Costa, Gandolfi e Costa (2002), adaptando os pressupostos metodológicos contidos em Zuquette (1993), apresenta a Carta de Áreas Preferenciais à Instalação de Aterros Sanitários da Região Metropolitana de Belém, na escala 1:50.000, elaborada mediante o cruzamento de informações topográficas, uso e ocupação do solo, áreas de proteção permanente (APPs) e unidades de conservação. Já Nishiyama, Menezes e Zuquette (2004) empregaram os procedimentos de mapeamento geotécnico, em escala 1:100.000, em uma porção do município de Uberlândia, Minas Gerais, visando à indicação de áreas mais favoráveis à disposição de resíduos sólidos. Para tanto, foram elaborados mapas do substrato rochoso, de materiais não consolidados, da profundidade do nível de água subterrâneo, das formas de relevo (landforms), da rede de drenagem, de declividade e do potencial de escoamento superficial.

Nesse período, em virtude da disseminação mundial da aplicação das técnicas de mapeamento geotécnico, a International Association of Engineering Geology (IAEG) publicou os trabalhos de Langer (1995) e Proske et al. (2005), considerados referência para a normatização de procedimentos de elaboração de mapas geotécnicos para a caracterização de adequabilidades para a disposição de rejeitos.

No cenário internacional, com o aumento da utilização de sistemas de informações geográficas como ferramenta para a classificação e o cruzamento de atributos, inúmeros trabalhos foram realizados haja vista a seleção de áreas para implantação de aterros sanitários, sobressaindo os produzidos por Sener, Süzen e Doyuran (2006), Ohri e Singh (2013), Rezaeimahmoudi et al. (2014) e Khan e Samadder 
(2014). Em muitos casos, a utilização de sistema de informações geográficas (SIG) vem acompanhada da aplicação de técnicas de análise multicritério e aplicação de lógica fuzzy, tais como descrito em Ersoy e Bulut (2009), Afzali et al. (2011), Donevska et al. (2012), Eskandari, Homaee e Mahmodi (2012), Isalou et al. (2013), Beskese et al. (2015) e Bahrani et al. (2016).

Recentemente, no Brasil, após a publicação da PNRS, Montaño et al. (2012) apresentaram uma abordagem metodológica que analisa a integração de critérios técnicos, ambientais e sociais em estudos de alternativas de localização de aterros sanitários em São Carlos, São Paulo.

Diante do exposto e tendo em vista a demanda de estudos gerada pela aplicação da PNRS na região sul da Bahia, este trabalho teve o objetivo de identificar áreas favoráveis à implantação de aterros sanitários nos municípios de Ilhéus, Itabuna, Uruçuca, Coaraci, Almadina e Barro Preto, inseridas nos limites da Bacia Hidrográfica do Rio Almada (BHRA), mediante o reconhecimento das características de atributos do meio físico que condicionam questões relacionadas à localização no relevo, aos materiais geológicos a serem utilizados, às condições relativas às escavações a serem realizadas e aos problemas ambientais que poderão ocorrer em decorrência da implantação e do uso desse tipo de empreendimento.

Para tanto, a metodologia empregada utilizou, na fase inicial, SIGs no processo de organização de informações digitais da área da bacia e dos municípios, a exemplo da base topográfica, do modelo digital do terreno (MDT) e da manipulação de imagens de satélite. Em fase intermediária, os produtos de mapeamentos temáticos da área, úteis no processo de avaliação das adequabilidades, foram organizados em um banco de dados digital no sentido de proporcionar os cruzamentos de atributos necessários ao zoneamento da área de acordo com a proposta metodológica de Zuquette (1993), incluindo adaptações referentes à utilização de atributos de uso e ocupação do solo e de legislação ambiental.

Dessa forma, o produto final gerado pela execução do trabalho constituiu um objeto cartográfico contendo o zoneamento da área dos municípios inseridos na BHRA, em classes de adequabilidade para a implantação de aterros sanitários resultantes da interação de características geológico-geotécnicas do meio físico e de suas fragilidades ambientais.

\section{METODOLOGIA}

A metodologia adotada para o entendimento da distribuição da adequabilidade à disposição ambiental de rejeitos na BHRA tem suas atividades divididas em quatro etapas, conforme apresentado nos Quadros 1 e 2.

A primeira etapa do método teve o propósito de caracterizar, pela elaboração de mapas básicos fundamentais, os principais componentes ambientais da BHRA (Quadro 1).

A segunda etapa do método objetivou interpretar as informações dos componentes ambientais produzidas e mapeadas na etapa 1 , tendo em vista o conhecimento das potencialidades e limitações do meio físico-ambiental para a finalidade de uso estudada (Quadro 2). Em função da área da bacia e da base planialtimétrica existente, os trabalhos de cartografia foram desenvolvidos na escala 1:100.000.

Quadro 1 - Etapas metodológicas para caracterização dos componentes físico-ambientais na elaboração da carta de adequabilidade à disposição ambiental de rejeitos na Bacia Hidrográfica do Rio Almada.

\begin{tabular}{|c|c|c|c|c|}
\hline Etapas & Objetivo & Componente & Fonte dos dados & Material e métodos \\
\hline \multirow{7}{*}{$\begin{array}{l}\text { Caracterização } \\
\text { dos componentes } \\
\text { físico-ambientais }\end{array}$} & \multirow{7}{*}{$\begin{array}{c}\text { Elaboração de } \\
\text { mapas básicos } \\
\text { fundamentais } \\
\text { e consolidação } \\
\text { de dados } \\
\text { preexistentes }\end{array}$} & $\begin{array}{l}\text { Substrato } \\
\text { rochoso }\end{array}$ & $\begin{array}{l}\text { "Programa Levantamentos } \\
\text { Geológicos Básicos do Brasil - Folha } \\
\text { SD.24-Y-B-Vl” (Arcanjo, 1997) }\end{array}$ & $\begin{array}{c}\text { Manipulação, em SIG, de arquivo shapefile. } \\
\text { Escala: 1:100.000. }\end{array}$ \\
\hline & & \multirow{2}{*}{ Relevo } & $\begin{array}{c}\text { Banco de Dados Geomorfométricos } \\
\text { do Brasil (INPE, 2008) }\end{array}$ & $\begin{array}{c}\text { Análise, em SIG, do MDT gerado pela manipulação de } \\
\text { dados matriciais disponíveis pelo Projeto TOPODATA. } \\
\text { Resolução: } 30 \times 30 \text { m. }\end{array}$ \\
\hline & & & Silva e Gomes (2010) & $\begin{array}{c}\text { Aplicação da técnica de avaliação do terreno e } \\
\text { manipulação de arquivos digitais (shapefile). } \\
\text { Escala: 1:100.000. }\end{array}$ \\
\hline & & Solos & Franco (2010) & $\begin{array}{c}\text { Manipulação em SIG de arquivo shapefile contendo as } \\
\text { diferentes classes de solos e suas características. } \\
\text { Escala: 1:100.000. }\end{array}$ \\
\hline & & $\begin{array}{l}\text { Uso e } \\
\text { ocupação } \\
\text { do solo }\end{array}$ & Gomes et al. (2013) & $\begin{array}{c}\text { Manipulação, em SIG, de arquivo shapefile contendo as } \\
\text { diferentes classes de uso e suas características. } \\
\text { Escala: 1:100.000. }\end{array}$ \\
\hline & & \multirow{2}{*}{$\begin{array}{l}\text { Recursos } \\
\text { hídricos }\end{array}$} & Gomes et al. (2013) & $\begin{array}{c}\text { Manipulação de arquivos digitais (shapefile) da rede de } \\
\text { drenagem da BHRA. Escala: 1:100.000. }\end{array}$ \\
\hline & & & $\begin{array}{l}\text { SIAGAS, desenvolvido pelo Serviço } \\
\text { Geológico do Brasil. }\end{array}$ & $\begin{array}{c}\text { Manipulação, em SIG, de arquivo shapefile contendo a } \\
\text { localização de poços profundos e suas características. } \\
\text { Escala: 1:100.000. }\end{array}$ \\
\hline
\end{tabular}

SIG: sistema de informações geográficas; MDT: modelo digital do terreno; BHRA: Bacia Hidrográfica do Rio Almada; SIAGAS: Sistema de Informações de Águas Subterrâneas. 
A terceira etapa do método focou em organizar as informações dos atributos do meio físico e de uso e ocupação do solo, definidos nas etapas 1 e 2, em classes de adequabilidade para a implantação de aterros sanitários de acordo com adaptações da proposta de Zuquette (1993) e inserções de alguns atributos, como distância das nascentes, fragilidade ambiental e presença de APP, agrupados em quatro fatores. Dessa maneira, os atributos, consolidados sob a forma de planos de informações em SIG, mais precisamente com a utilização do software ArcGIS 10, licenciado pelo Laboratório de Geoprocessamento da Universidade Estadual de Santa Cruz (UESC), foram subdivididos em quatro grupos, denominados de fator geotécnico, fator geomorfológico, fator geoambiental e fator de uso e ocupação do solo, e tiveram suas características e seus valores enquadrados em quatro classes de adequabilidade ("favorável", "moderada", "severa" e "restritiva”) (Quadro 3).

A quarta etapa constituiu na agregação dos planos de informações dos quatro fatores avaliados, considerando a geração da carta de adequabilidade para a disposição ambiental de rejeitos na BHRA. Para tanto, foi estabelecido um valor de peso a cada classe de adequabilidade variável, de 1 a 4 : peso 4 para a classe favorável, 3 para a classe moderada, 2 para a classe severa, e peso 1 para a classe restritiva.

Logo, o valor medido e representativo de cada atributo foi convertido em um número variável de 1 a 4 , em função de seu enquadramento nas classes de adequabilidade. Feito isso, em ambiente de SIG, com a utilização do ArcGIS 10, foi aplicada álgebra de mapas nos planos de informações dos atributos com o objetivo de estabelecer o valor médio de adequabilidade para cada um dos quatro fatores estudados. Em seguida, os fatores foram somados e foi encontrada a sua média representativa do valor de adequabilidade dos quatro fatores avaliados. A Equação 1 demonstra o algoritmo utilizado na ponderação dos atributos:

$\mathrm{ADR}=[(\mathrm{SR}+\mathrm{NH}+\mathrm{PSR}+\mathrm{TS}+\mathrm{SL}+\mathrm{SE}) / 6]^{\star} 0,25+$

$[(\mathrm{DE}+\mathrm{DN}+\mathrm{FD}) / 3]^{\star} 0,25+\mathrm{FA}^{\star} 0,25+[(\mathrm{AP}+\mathrm{US}) / 2]^{\star} 0,25$

Em que:

$\mathrm{ADR}$ = adequabilidade para a disposição ambiental de rejeitos;

$\mathrm{SR}=$ substrato rochoso;

$\mathrm{NH}=$ profundidade do nível de água;

$\mathrm{PSR}=$ profundidade do substrato rochoso;

TS = textura dos solos;

SL = susceptibilidade à erosão laminar;

$\mathrm{SE}=$ susceptibilidade a escorregamentos em encostas;

$\mathrm{DE}=$ declividade;

$\mathrm{DN}=$ distância das nascentes;

$\mathrm{FD}=$ frequência de canais de drenagem;

Quadro 2 - Etapas metodológicas para interpretação das informações dos componentes ambientais na elaboração da carta de adequabilidade para a disposição ambiental adequada de rejeitos na Bacia Hidrográfica do Rio Almada.

\begin{tabular}{|c|c|c|c|c|}
\hline Etapa & Objetivo & Atributo & Fonte dos dados & Material e métodos \\
\hline \multirow{8}{*}{$\begin{array}{l}\text { Interpretar as } \\
\text { informações dos } \\
\text { componentes } \\
\text { ambientais }\end{array}$} & \multirow{8}{*}{$\begin{array}{c}\text { Conhecimento } \\
\text { das } \\
\text { potencialidades } \\
\text { e limitações do } \\
\text { meio físico- } \\
\text { ambiental para } \\
\text { implantação } \\
\text { da finalidade } \\
\text { estudada }\end{array}$} & $\begin{array}{l}\text { Profundidade do } \\
\text { nível de água } \\
\text { Profundidade do } \\
\text { substrato rochoso }\end{array}$ & $\begin{array}{l}\text { SIAGAS, } \\
\text { desenvolvido pelo } \\
\text { Serviço Geológico } \\
\text { do Brasil. }\end{array}$ & $\begin{array}{l}\text { Para a extrapolação lateral das informações pontuais dos poços, } \\
\text { foram utilizados os limites e a distribuição das manchas do mapa } \\
\text { de landforms. } \\
\text { Escala: 1:100.000. }\end{array}$ \\
\hline & & Textura dos solos & Franco (2010) & $\begin{array}{l}\text { Manipulação, em SIG, de arquivo shapefile contendo as } \\
\text { características da textura dos solos. Escala: 1:100.000. }\end{array}$ \\
\hline & & $\begin{array}{l}\text { Frequência } \\
\text { de canais de } \\
\text { drenagem }\end{array}$ & $\begin{array}{l}\text { MDT e Silva e } \\
\text { Gomes (2010) }\end{array}$ & $\begin{array}{l}\text { Razão entre o somatório do comprimento de canais de drenagem } \\
\text { e a área da unidade de terreno em que se encontram os canais. }\end{array}$ \\
\hline & & $\begin{array}{l}\text { Susceptibilidade à } \\
\text { erosão laminar }\end{array}$ & Gomes (2016) & $\begin{array}{l}\text { Em ambiente SIG, aplicação da EUPS proposta por Wischmeier e } \\
\text { Smith (1978). } \\
\text { Escala: 1:100.000. }\end{array}$ \\
\hline & & $\begin{array}{l}\text { Susceptibilidade a } \\
\text { escorregamentos }\end{array}$ & Gomes (2016) & $\begin{array}{c}\text { Aplicação do modelo SINMAP desenvolvido por Pack et al. (1998). } \\
\text { Escala: 1:100.000. }\end{array}$ \\
\hline & & $\begin{array}{l}\text { Distância das } \\
\text { nascentes }\end{array}$ & $\begin{array}{l}\text { Gomes et al. } \\
\text { (2013) }\end{array}$ & 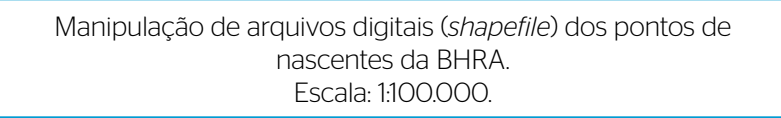 \\
\hline & & $\begin{array}{l}\text { Fragilidade } \\
\text { ambiental }\end{array}$ & Gomes (2013) & $\begin{array}{c}\text { Dados do meio físico e de uso e ocupação do solo foram } \\
\text { avaliados tendo em vista o conhecimento de suas fragilidades e } \\
\text { vulnerabilidades de acordo com a proposta de Ross (1994) } \\
\text { Escala: 1:100.000. }\end{array}$ \\
\hline & & APPS & $\begin{array}{l}\text { Gomes et al. } \\
\quad(2013)\end{array}$ & $\begin{array}{l}\text { Manipulação, em SIG, de arquivos digitais representando as APPs } \\
\text { da BHRA (shapefile). } \\
\text { Escala: 1:100.000. }\end{array}$ \\
\hline
\end{tabular}

SIG: sistema de informações geográficas; MDT: modelo digital do terreno; BHRA: Bacia Hidrográfica do Rio Almada; EUPS: equação universal de perdas de solo; SINMAP: stability index mapping; APPs: áreas de preservação permanente. 
$\mathrm{FA}=$ fragilidade ambiental;

$\mathrm{AP}=$ presença de áreas de preservação permanente; $\mathrm{e}$

US = uso e ocupação do solo.

\section{RESULTADOS E DISCUSSÃO}

\section{Caracterização físico-ambiental da área estudada}

As Figuras 1 a 4 apresentam informações dos aspectos físico-ambientais da BHRA, apresentados sob a forma de mapas temáticos básicos confeccionados na primeira etapa do método. Detalhes sobre os dados de caracterização da área podem ser obtidos em Gomes et al. (2012). Quanto às características do substrato rochoso da BHRA, ele é composto, predominantemente, de rochas do embasamento cristalino de idade pré-cambriana agrupadas nos denominados complexos Ibicaraí-Buerarema, São José e Almadina; além de granitoides granulitizados e magmatismos de idade brasiliana, representados por sienitos da suíte intrusiva Itabuna, corpos de básicas intrusivas e diques máficos. Com relação às coberturas sedimentares fanerozoicas, elas englobam os sedimentos mesozoicos da Bacia Sedimentar do Rio Almada, mais precisamente conglomerados, arenitos, siltitos e argilitos que compõem as formações Sergi, Itaparica, Candeias e Urucutuca e o Grupo Ilhas, além dos sedimentos arenoargilosos tércio-quaternários da Formação Barreiras e dos sedimentos recentes das planícies quaternárias (Figura 1).

Do ponto de vista geomorfológico, os modelados de acumulação associam-se, principalmente, a formas de acumulação marinha (cordões arenosos e planícies costeiras), acumulações fluviais (depósitos de canal e de planícies aluvionares), praias e mangues atuais. De modo geral, essas áreas possuem valores de declividade do relevo menores que $5 \%$ (Figura 2). Já os modelados de dissecação referem-se às unidades de relevo resultantes do processo de dissecação de rochas do embasamento cristalino e de sedimentos mesozoicos da Bacia Sedimentar do Rio Almada, resultando em formas de morros e colinas. Nesse contexto, as declividades compreendidas entre 5 e $20 \%$ associam-se, preferencialmente, à zona superior da encosta, caracterizando-se como transição entre as áreas de topo e a porção da encosta mais íngreme. As classes maiores que $20 \%$ ocorrem no trecho de meia encosta variando em função da concavidade da vertente e bastante distribuída nas porções central e oeste da bacia.

Já os solos identificados na BHRA distribuem-se em conformidade com as mudanças em seus aspectos litológicos e geomorfológicos (Figura 3). De acordo com o mapeamento realizado por Franco (2010), os principais tipos de solo da BHRA, em termos de primeiro

Quadro 3 - Classes dos atributos físico-ambientais para a avaliação de áreas para disposição de rejeitos na Bacia Hidrográfica do Rio Almada.

\begin{tabular}{|c|c|c|c|c|c|}
\hline \multirow{2}{*}{ Fator } & \multirow{2}{*}{ Atributo } & \multicolumn{4}{|c|}{ Classes de adequabilidade } \\
\hline & & Favorável & Moderada & Severa & Restritiva \\
\hline \multirow{7}{*}{ Geotécnico } & Substrato rochoso & $\begin{array}{l}\text { Gnaisses, migmatitos, } \\
\text { siltitos e argilitos }\end{array}$ & Granitos & Conglomerados & Arenitos \\
\hline & $\begin{array}{l}\text { Profundidade do nível de água } \\
\text { subterrâneo (m) }\end{array}$ & $>10$ & $>6$ & $<4$ & $<2$ \\
\hline & Profundidade do substrato rochoso (m) & $>15$ & $5-10$ & $5-3$ & $<3$ \\
\hline & Distância das nascentes (m) & $>500$ & $400-500$ & $400-300$ & $<300$ \\
\hline & Textura dos solos & Areia argilosa & Argila arenosa & Arenosa & Muito arenosa \\
\hline & $\begin{array}{c}\text { Susceptibilidade à erosão laminar - } \\
\text { USLE (t/ha/ano) }\end{array}$ & $<10$ & $10-50$ & $50-200$ & $>200$ \\
\hline & $\begin{array}{l}\text { Susceptibilidade a escorregamentos } \\
\text { em encostas - SINMAP (IE) }\end{array}$ & $>1,5$ & $1-1,5$ & $0,5-1$ & $<0,5$ \\
\hline \multirow[b]{2}{*}{ Geomorfológico } & Declividade (\%) & $2-5$ & $5-15$ & & $2-5$ \\
\hline & $\begin{array}{l}\text { Frequência de canais de drenagem } \\
\text { (número de canais/km) }\end{array}$ & $<1$ & $2-3$ & $3-4$ & $>4$ \\
\hline Geoambiental & Fragilidade Ambiental & $1-1,75$ & $1,75-2,5$ & $2,5-3,25$ & $3,25-4,0$ \\
\hline \multirow{2}{*}{$\begin{array}{l}\text { Uso e ocupação } \\
\text { do solo }\end{array}$} & Presença de APPs & - & - & - & APP \\
\hline & Uso e ocupação do solo & $\begin{array}{l}\text { Areas degradadas e } \\
\text { pastagens }\end{array}$ & Gramíneas & $\begin{array}{c}\text { Floresta associada à } \\
\text { cultura }\end{array}$ & $\begin{array}{l}\text { Areas úmidas e } \\
\quad \text { floresta }\end{array}$ \\
\hline
\end{tabular}

Fonte: adaptada de Zuquette (1993).

SINMAP: stability index mapping; APPs: áreas de preservação permanente; USLE: Universal Soil Loss Equation; IE: Índice de Estabilidade. 


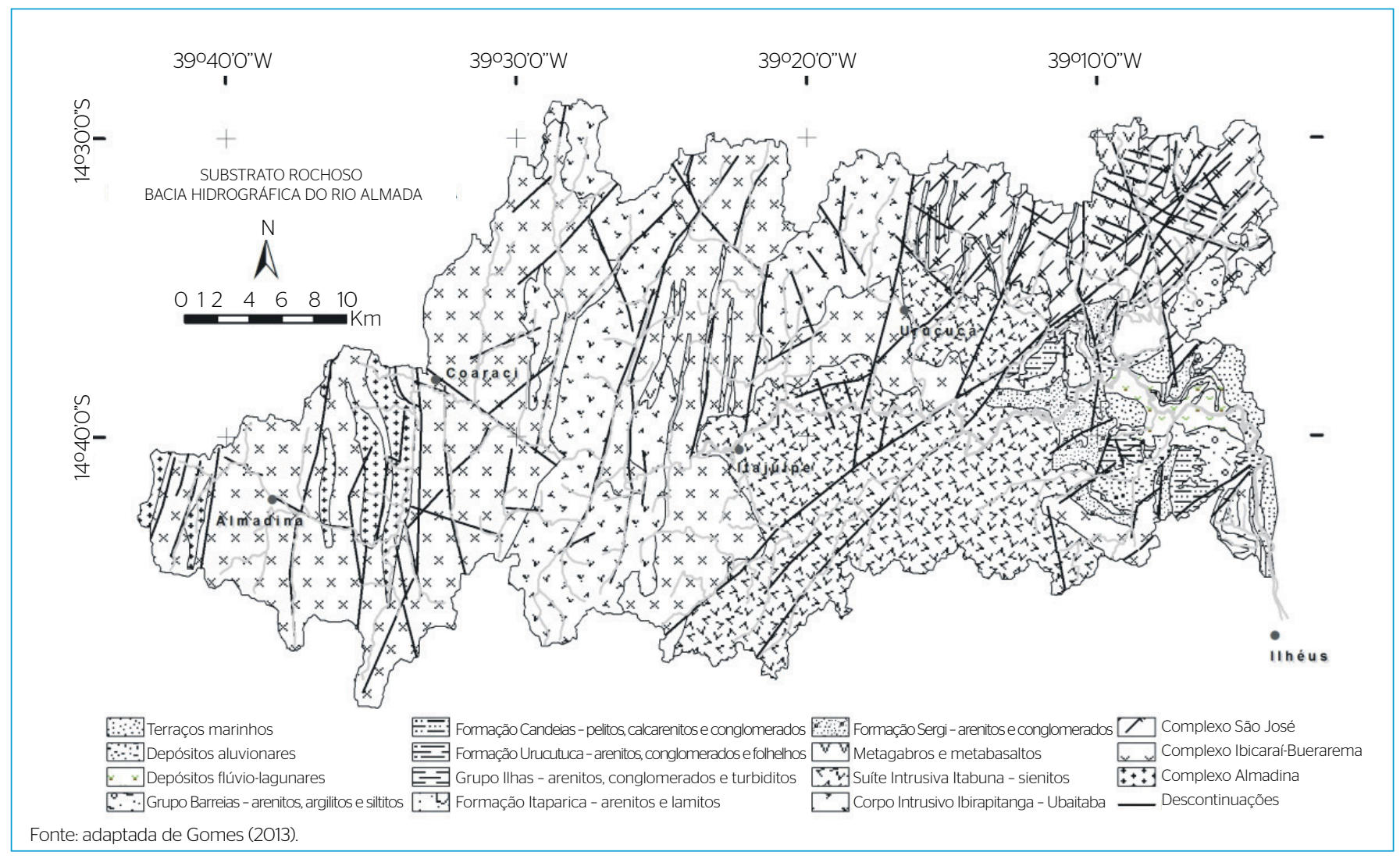

Figura 1 - Substrato rochoso da Bacia Hidrográfica do Rio Almada.

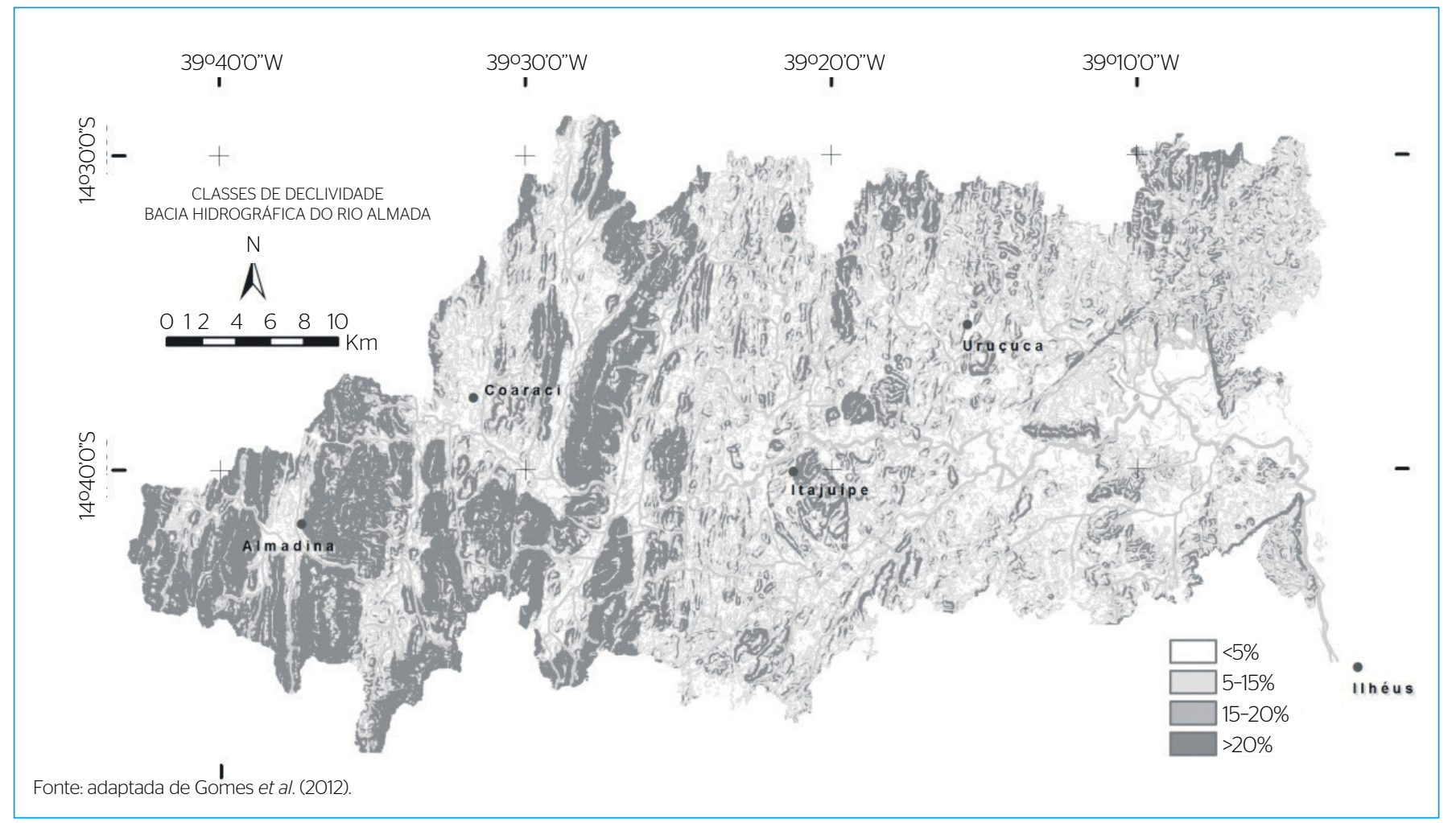

Figura 2 - Classes de declividade da Bacia Hidrográfica do Rio Almada. 
nível categórico, são: neossolos, espodossolos, latossolos, argissolos, luvissolos e vertissolos.

De acordo com Gomes et al. (2012), a distribuição das classes de uso e ocupação do solo da área em estudo apresenta o cenário em que o somatório de áreas consideradas antropizadas, que compreendem as classes de pastagens, o solo exposto e as áreas urbanas, representa $24 \%$ da área total da bacia, enquanto o total das áreas de floresta, "cabruca", gramíneas e úmidas/manguezais corresponde a 73,7\% (Figura 4). O restante refere-se às classes de áreas de superfície aquática associadas à rede de drenagem da bacia e à Lagoa Encantada, além de áreas não classificadas pela ocorrência de nuvens. Ressalta-se que, neste trabalho, se pensou na espécie "cabruca" implantada no sub-bosque como um sistema ecológico de cultivo agroflorestal e que permite o concílio do cacau com a floresta.

De acordo com Gomes et al. (2013), as áreas antropizadas por pastagens, solo exposto e urbanização representam, em média, 28\% do uso do solo das APP da BHRA, enquanto as áreas de cobertura vegetal natural, representadas pela Mata Atlântica e pelos manguezais, constituem cerca de 25\% dessa ocupação. A "cabruca" (Mata Atlântica raleada sobre plantação de cacau) tem $29 \%$ de representatividade.

\section{Adequabilidade dos atributos físico-ambientais para a disposição ambiental de rejeitos}

\section{Adequabilidade da litologia e profundidade do substrato rochoso}

$\mathrm{Na}$ área de ocorrência do complexo cristalino, a adequabilidade do substrato rochoso varia de favorável a moderada. A adequabilidade favorável distribui-se desde as porções oeste a leste da bacia e está associada às ocorrências de rochas do complexo metamórfico do embasamento cristalino. Por outro lado, a ocorrência, com trend norte-sul, do granitoide granulitizado do corpo intrusivo Ibirapitanga-Ubaitaba, em virtude de seu maior grau de faturamento e de diferenças em seu perfil de alteração, diminui a adequabilidade para classe moderada em sua área de afloramento localizada na parte central da bacia (Figura 5). Já na porção leste, as características dos sedimentos mesozoicos da Bacia Sedimentar do Rio Almada, dos sedimentos não consolidados da Formação Barreiras e dos sedimentos arenosos marinhos da planície costeira, todos com características de alta permeabilidade e porosidade, tornam a adequabilidade restrita nessas áreas.

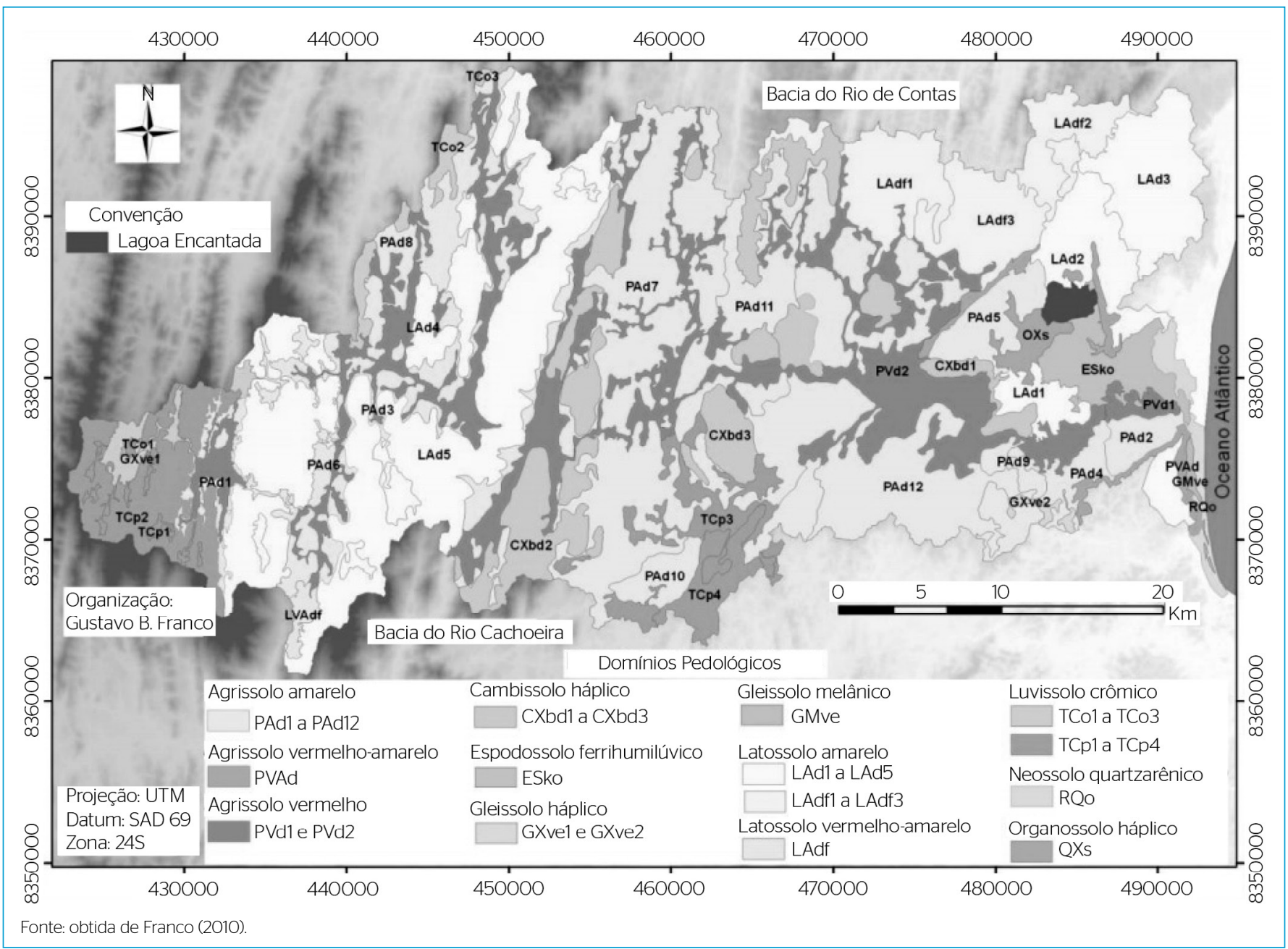

Figura 3 - Classes de solos da bacia hidrográfica do Rio Almada. 
Com relação à espessura do manto de alteração, ou seja, a profundidade do topo do substrato rochoso, a porção oeste da bacia apresenta adequabilidade que varia, predominantemente, de severa a restritiva, em virtude da ocorrência de perfis de alteração de pequena espessura e baixa maturidade textural, mostrando-se, muitas vezes, pedregosos. Essas características podem ser observadas nos perfis de alteração localizados na porção oeste da bacia, a partir da cidade de Itajuípe, onde o substrato rochoso, formado por metassedimentos

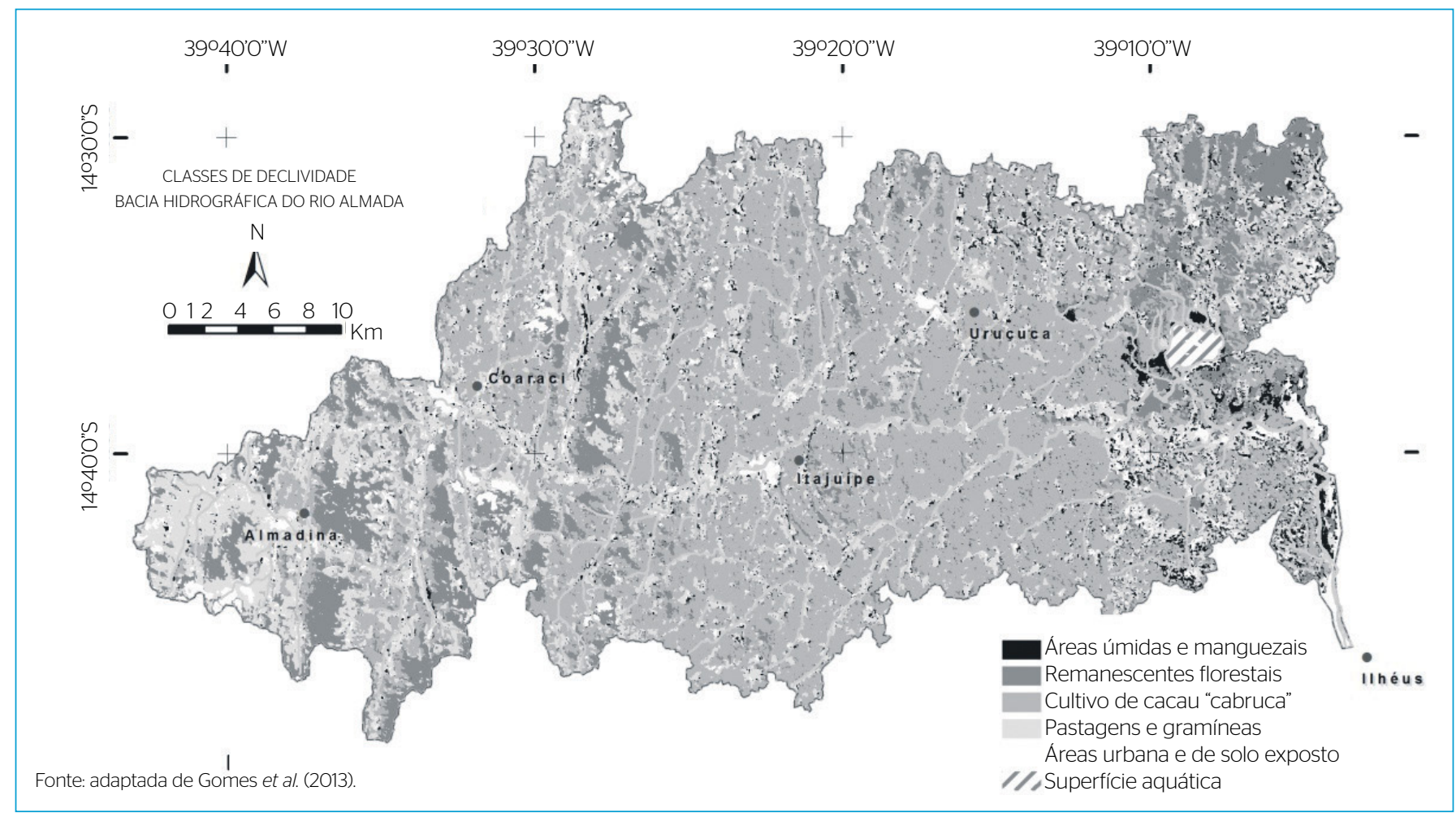

Figura 4 - Classes de uso e ocupação do solo da Bacia Hidrográfica do Rio Almada.

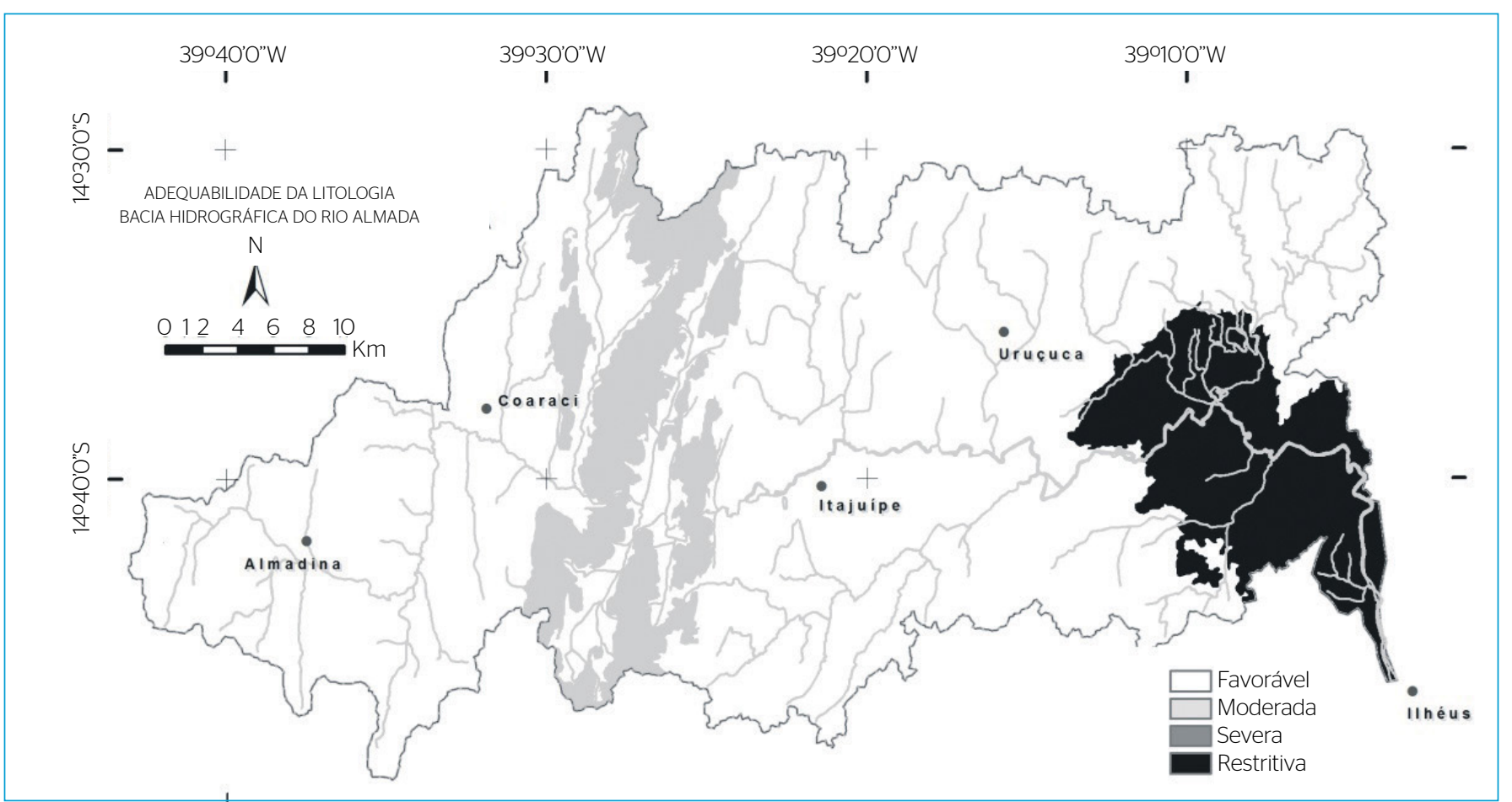

Figura 5 - Distribuição da adequabilidade da litologia na área da Bacia Hidrográfica do Rio Almada. 
granulitizados e corpos de granitoides, sustenta um relevo de morros e serras (Figura 6). Já na parte central da bacia predomina a adequabilidade favorável, em função do aumento de espessura dos perfis de alteração do substrato cristalino. Na porção leste, a adequabilidade volta a ser de severa a restritiva, em virtude da pouca espessura dos sedimentos arenosos da planície costeira e dos solos pouco desenvolvidos associados à Formação Barreiras.

\section{Adequabilidade da profundidade do nível de água subterrâneo e da distância das nascentes}

A classe de adequabilidade severa para o atributo "profundidade do nível de água subterrâneo" possui ocorrência controlada pela distribuição dos sedimentos mesozoicos da Bacia Sedimentar do Rio Almada e dos sedimentos recentes inconsolidados da planície costeira, podendo aumentar a restrição em áreas de ocorrência de alagamentos, predominantemente localizadas nas proximidades da calha do Rio Almada em seu trecho costeiro (Figura 7). Por sua vez, os valores favoráveis associam-se às porções mais elevadas do relevo. Com relação à distância das nascentes, os buffers distribuem-se por toda a bacia, sendo mais intensos onde a densidade da rede de drenagem é maior, a exemplo das áreas serranas localizadas na porção oeste da área em estudo (Figura 8).

\section{Adequabilidade da textura dos solos}

Nas áreas de ocorrência de solos com textura predominantemente arenoargilosa a argiloarenosa, a exemplo dos argissolos e dos luvissolos, que ocorrem nas partes central e oeste da bacia, predominam, respectivamente, as classes de adequabilidade moderada a severa (Figura 9). Já a adequabilidade restritiva ocorre associada a solos de textura predominantemente na fração areia, a exemplo das áreas de domínio dos espodossolos e neossolos quartzarênicos, localizados na porção litorânea da bacia.

\section{Adequabilidade das susceptibilidades à erosão laminar e a escorregamentos em encostas}

A susceptibilidade à erosão laminar na área da BHRA, calculada mediante a aplicação da equação universal de perda de solo proposta por Gomes (2016), remete-se a um cenário em que as classes de adequabilidade severa e moderada associam-se às áreas mais íngremes do relevo, ocorrentes de forma predominante na porção oeste da bacia (Figura 10). Comportamento semelhante dá-se com relação à adequabilidade da susceptibilidade a escorregamentos em encostas (GOMES, 2016), em que, de forma geral, as classes de adequabilidade moderada, severa e restritiva acontecem associadas às encostas íngremes do relevo serrano da porção oeste da bacia (Figura 11).

\section{Adequabilidade da declividade e da frequência dos canais de drenagem}

Conforme exposto na Figura 12, as classes de adequabilidade severa e restritiva para o atributo "declividade" ocorrem de forma mais expressiva na porção oeste da BHRA, mais precisamente a partir da cidade de Itajuípe,

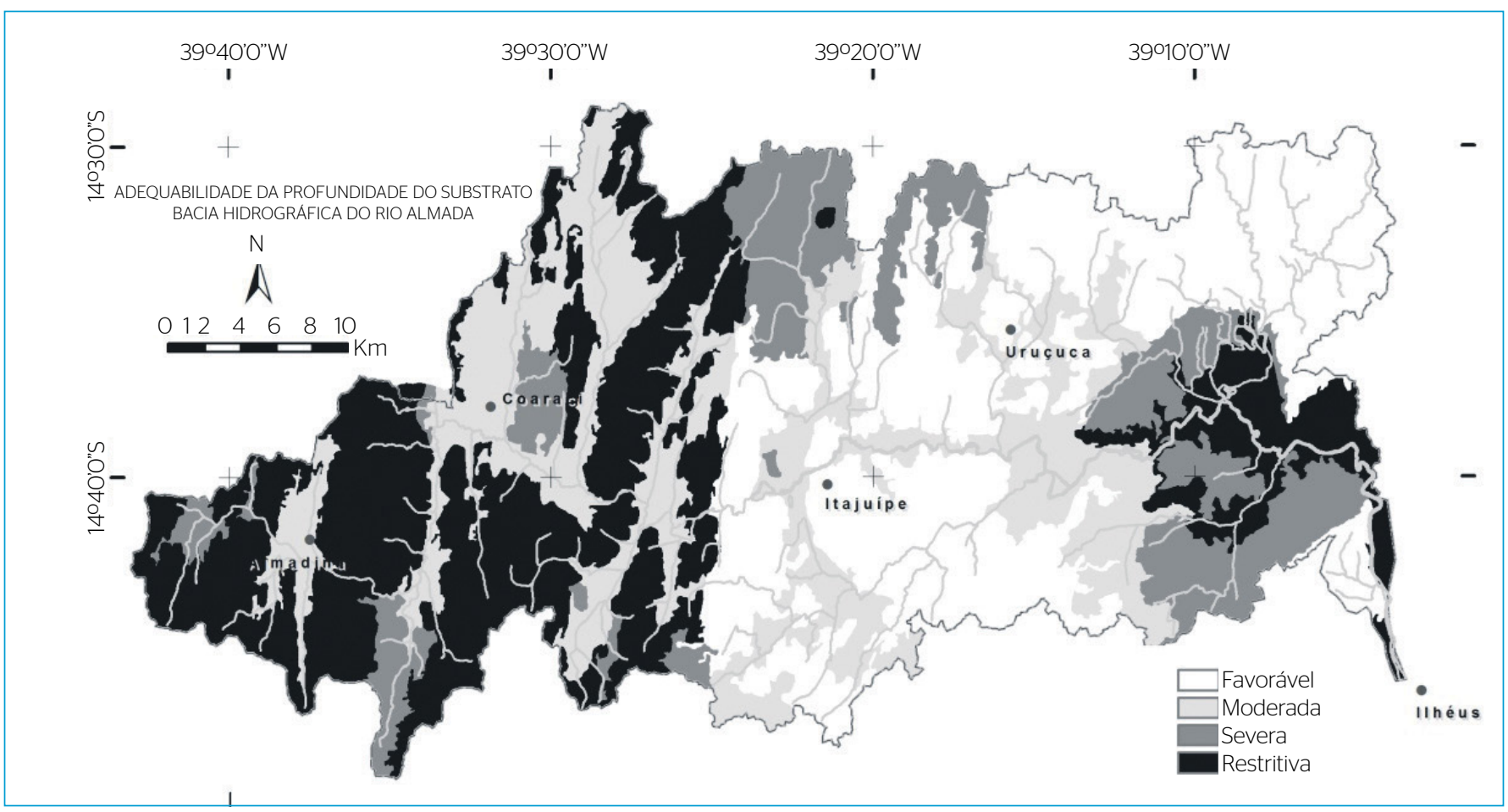

Figura 6 - Distribuição da adequabilidade da profundidade do substrato rochoso na área da Bacia Hidrográfica do Rio Almada. 
onde predominam morros e serras com amplitudes que variam de $200 \mathrm{a}$ $600 \mathrm{~m}$ e topos que alcançam altitudes de até $1.040 \mathrm{~m}$. Nas outras partes da bacia são verificadas, de forma mais proeminente, as classes de adequabilidade favorável a moderada com bolsões de adequabilidade severa associados a zonas de morros isolados e distribuídos na porção nordeste em área da Serra do Conduru. Já a adequabilidade da frequência dos canais de drenagem ocorre de forma favorável em grande parte da bacia, variando para moderada quando da proximidade dos fundos de vale (Figura 13).

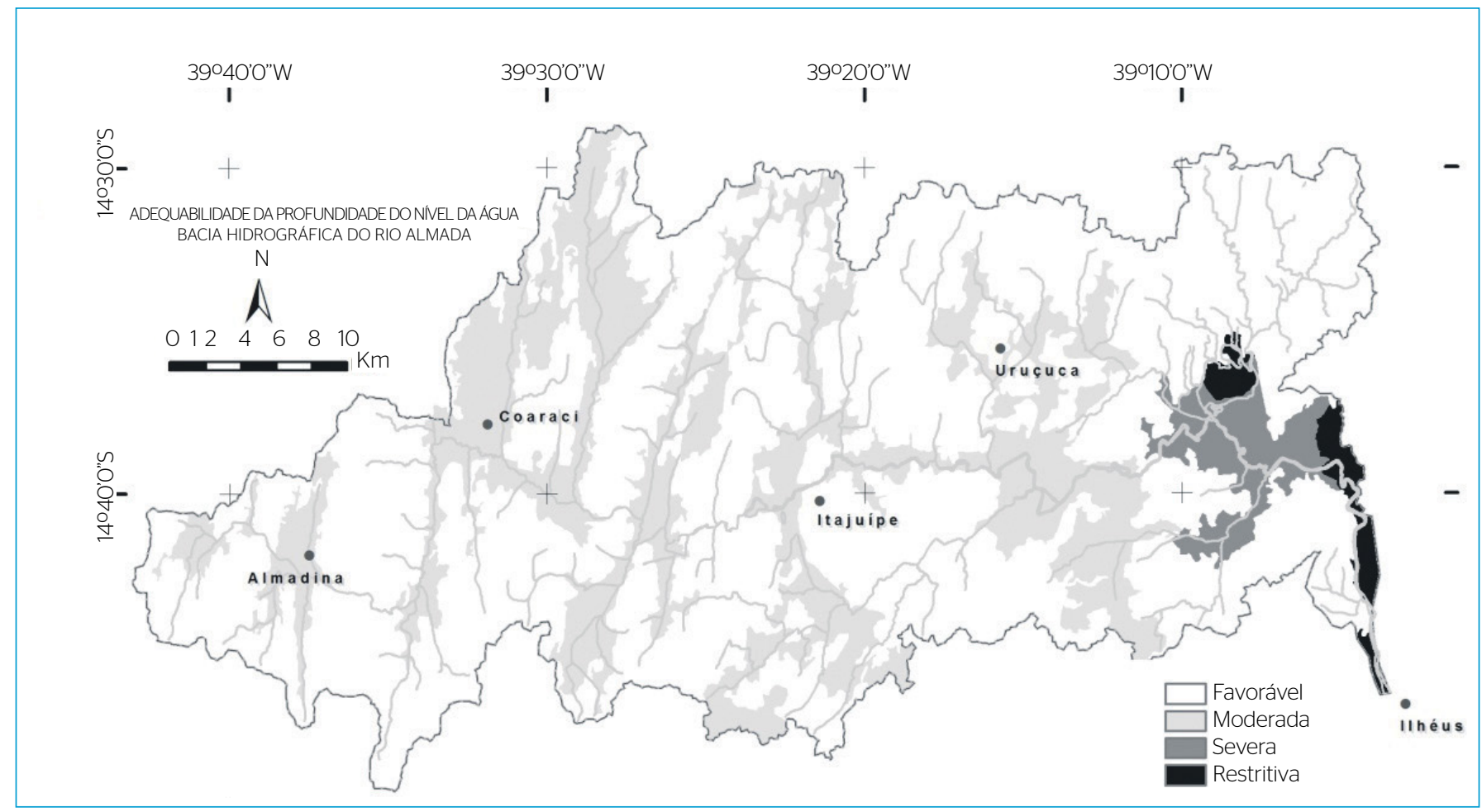

Figura 7 - Distribuição da adequabilidade da profundidade do nível de água subterrâneo na área da Bacia Hidrográfica do Rio Almada.

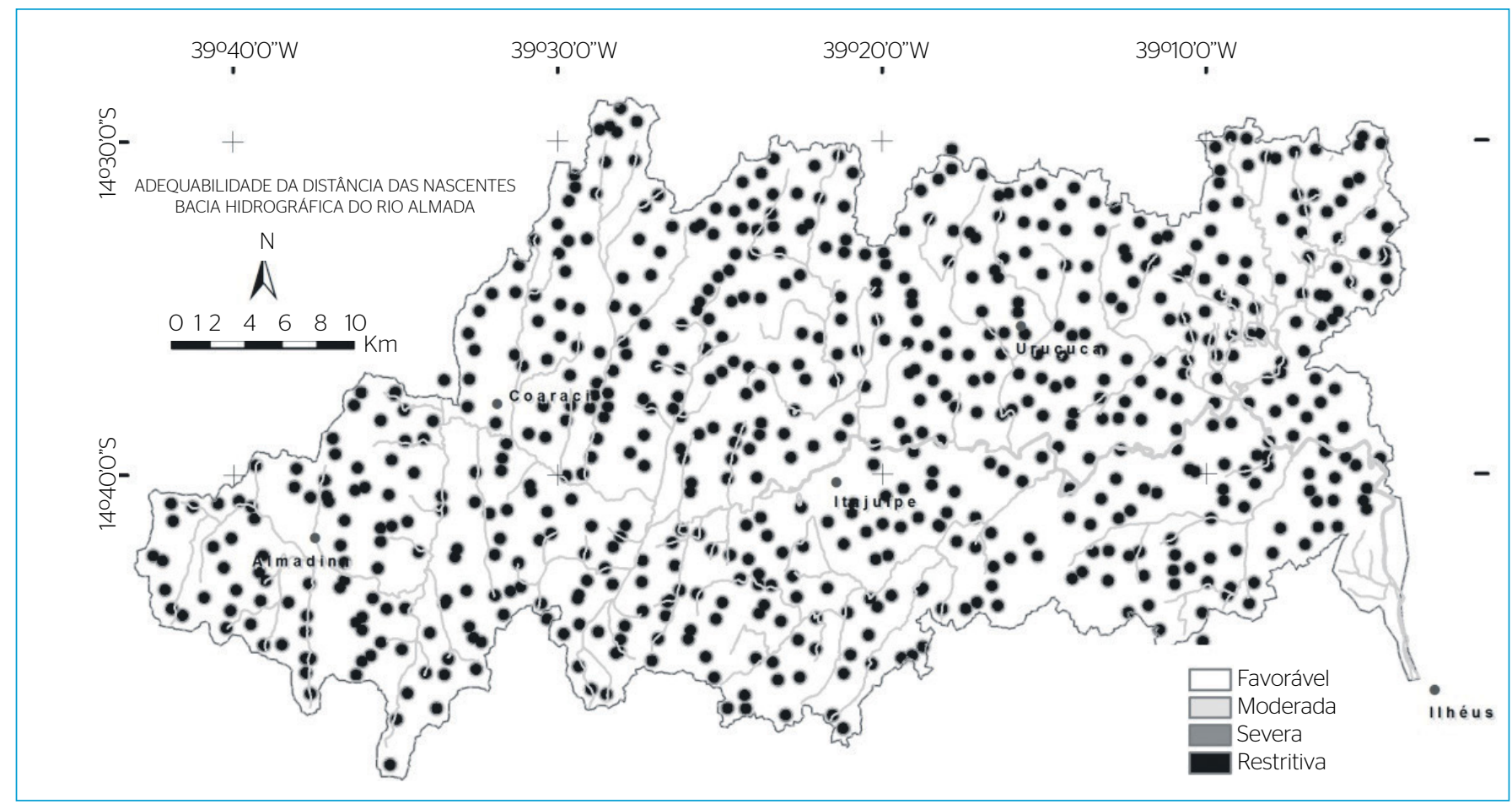

Figura 8 - Distribuição da adequabilidade da distância das nascentes na área da Bacia Hidrográfica do Rio Almada. 


\section{Adequabilidade da fragilidade ambiental}

Conforme exposto na metodologia, a fragilidade ambiental da BHRA, mapeada no trabalho de Gomes (2013), mostrou que a distribuição das classes de adequabilidade severa e restritiva se associa, predominantemente, aos trechos com declividades superiores a $20 \%$ situados na porção oeste da bacia e às áreas de ocorrência de substrato rochoso sedimentar, tanto relacionados aos sedimentos mesozoicos quanto aos sedimentos não consolidados recentes (Figura 14).

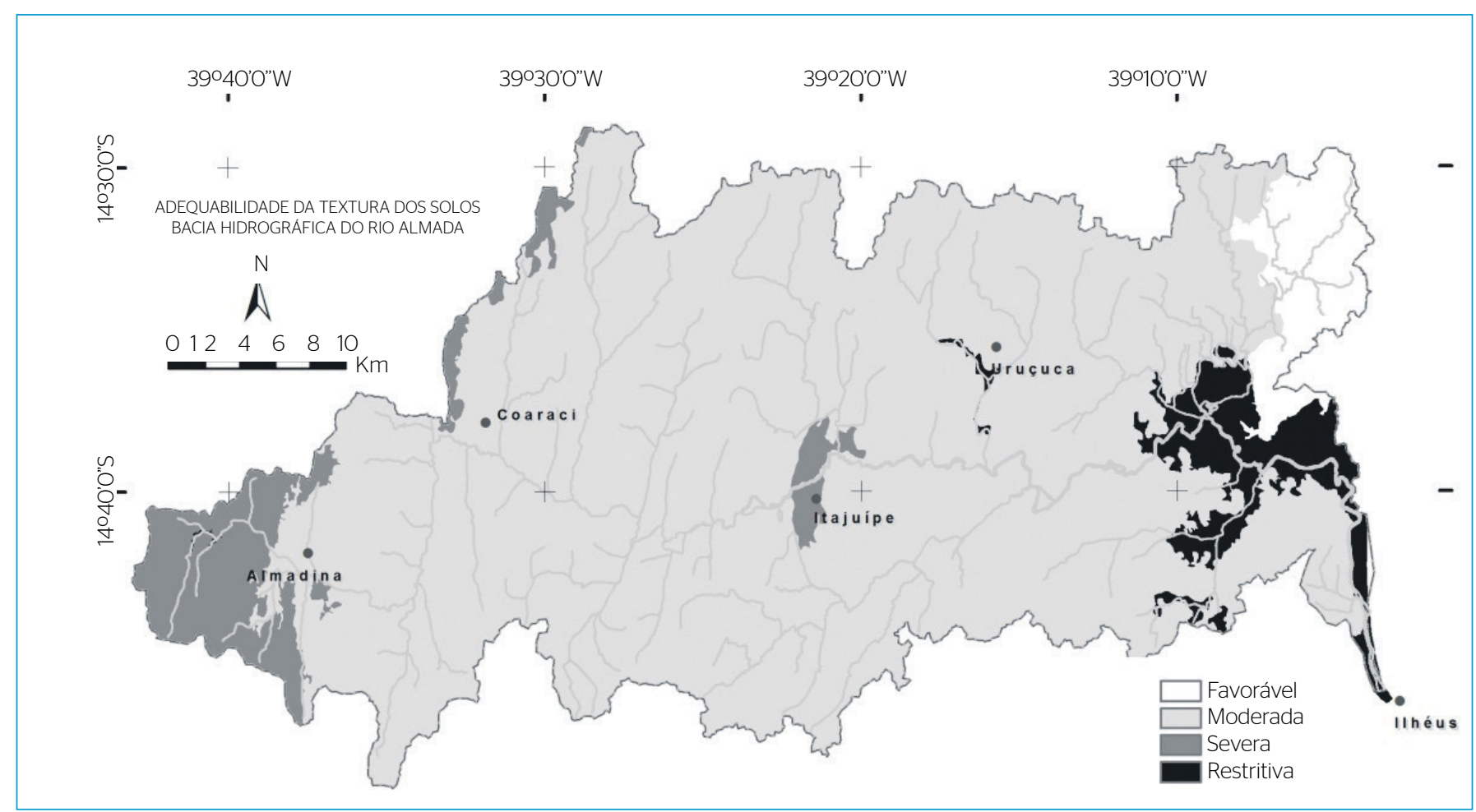

Figura 9 - Distribuição da adequabilidade da textura de solos na área da Bacia Hidrográfica do Rio Almada.

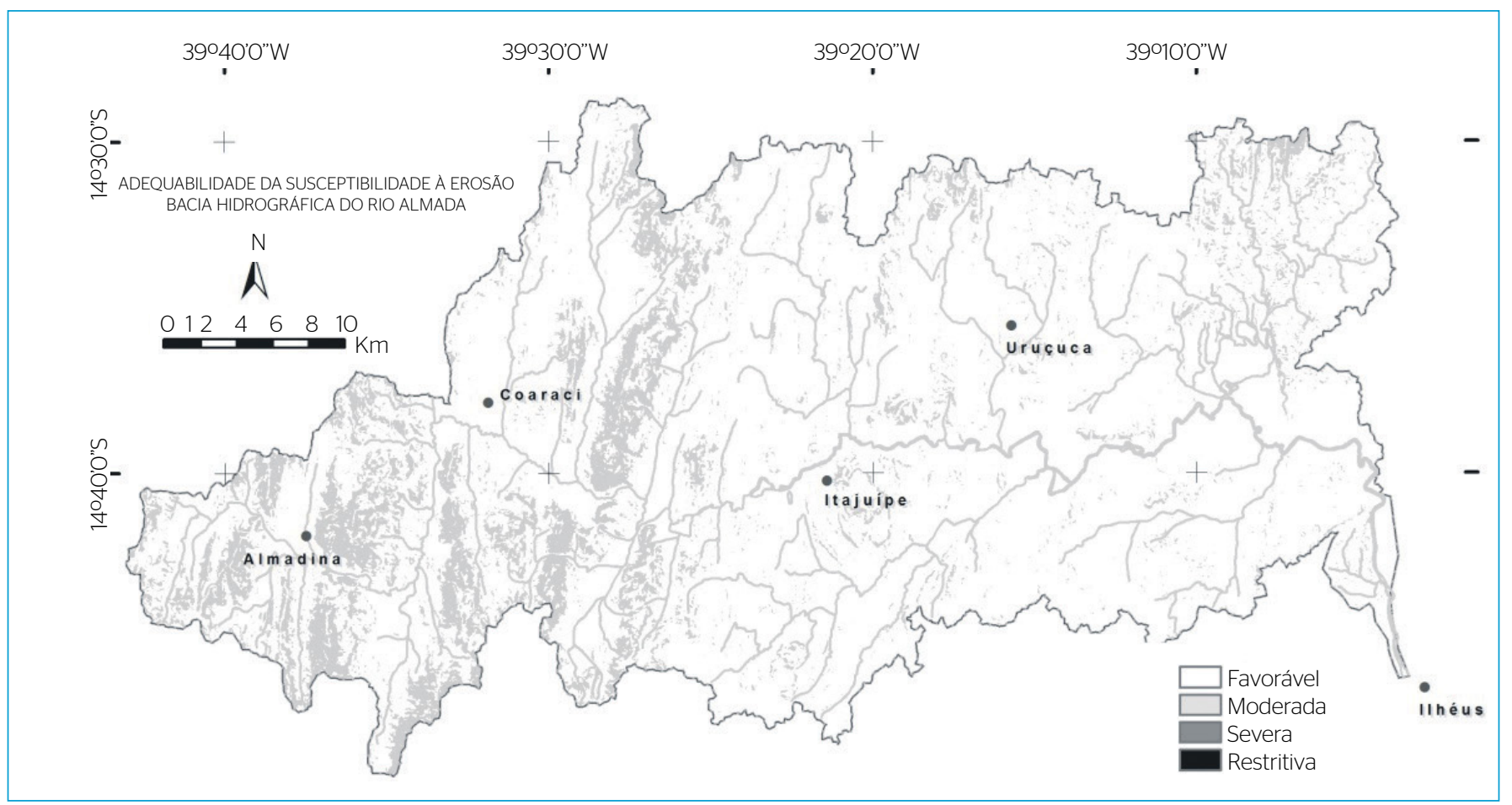

Figura 10 - Distribuição da adequabilidade à erosão laminar de solos na área da Bacia Hidrográfica do Rio Almada. 
$\mathrm{Na}$ BHRA, a classe de adequabilidade moderada predomina em áreas associadas à distribuição do substrato rochoso cristalino e, preferencialmente, onde se desenvolvem as classes de solos dos latossolos e argissolos. Já a classe de adequabilidade favorável associa-se às calhas da rede de drenagem, em virtude das baixas declividades.

\section{Adequabilidade da presença de áreas de} preservação permanente e de uso e ocupação do solo

Com relação ao atributo de uso e ocupação do solo, as classes de adequabilidade severa e restritiva associam-se, nessa ordem, a porções da bacia cobertas por cultivo do cacau "cabruca" e por remanescentes

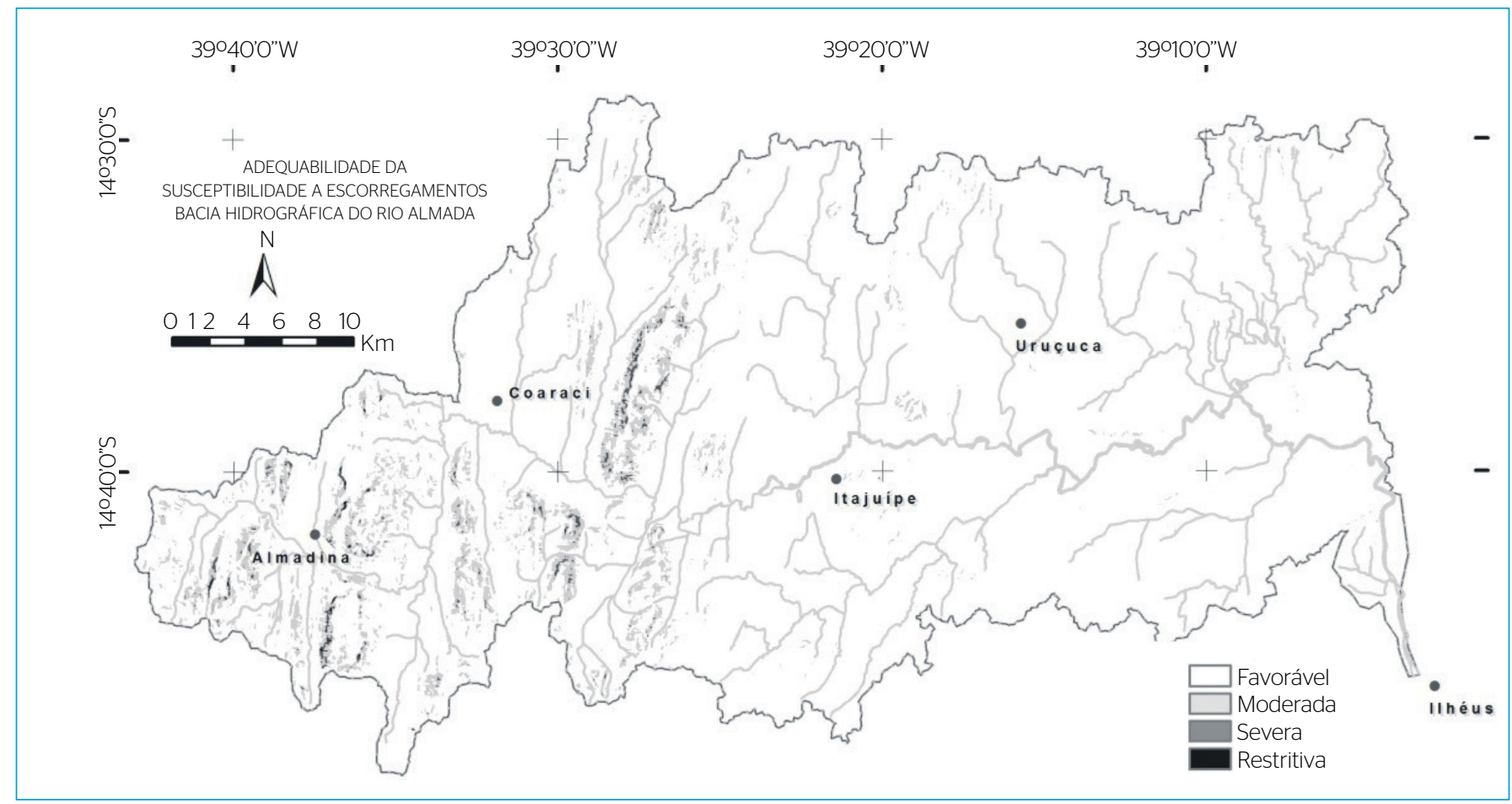

Figura 11 - Distribuição da adequabilidade à ocorrência de escorregamentos em encostas na área da Bacia Hidrográfica do Rio Almada.

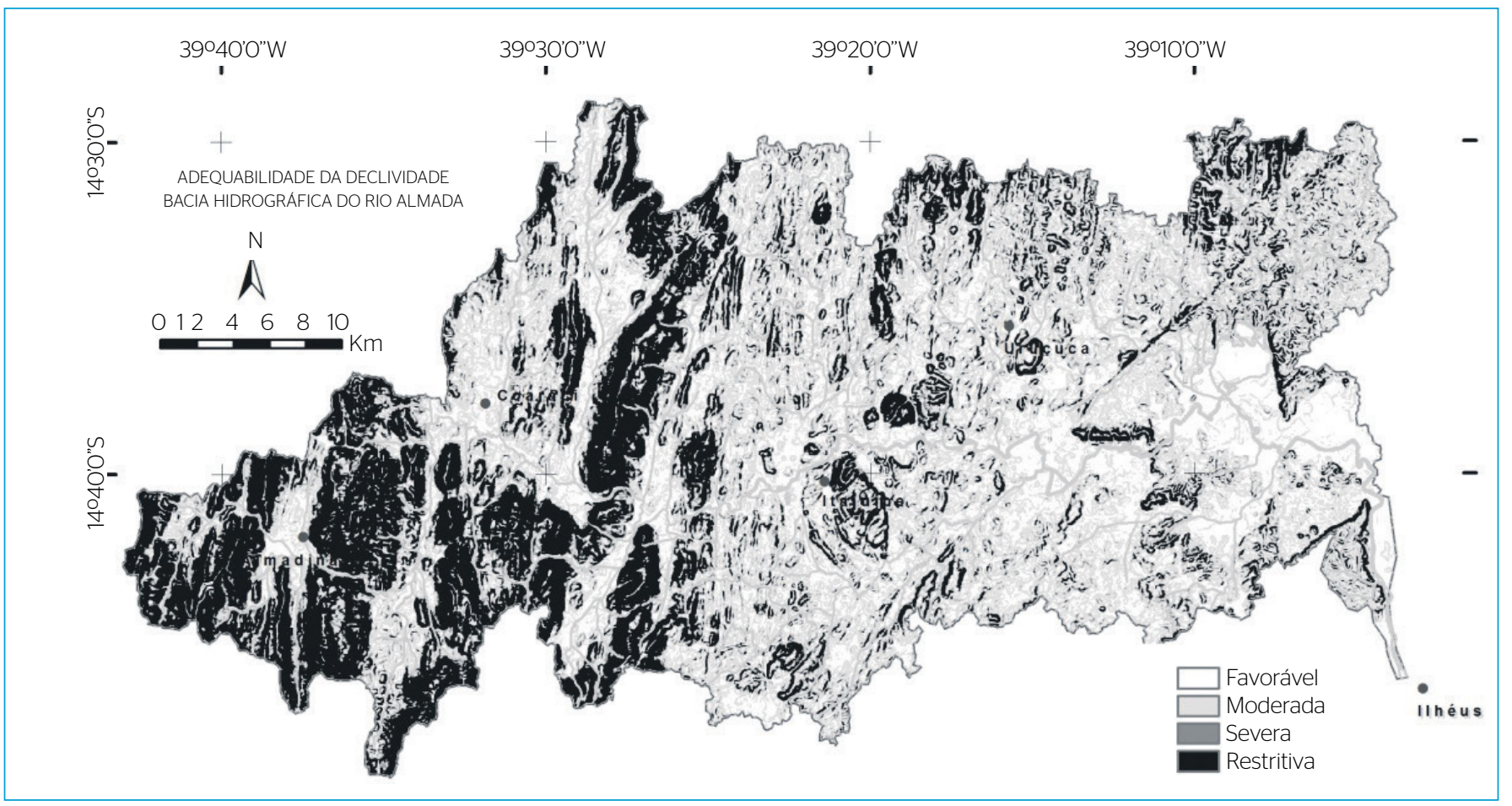

Figura 12 - Distribuição da adequabilidade à declividade na área da Bacia Hidrográfica do Rio Almada. 
florestais. De maneira geral, tais remanescentes ocorrem predominantemente em áreas mais preservadas associadas ao Parque Estadual da Serra do Conduru, localizado na porção nordeste da bacia, e aos topos de morros e serras da porção oeste. Já o cultivo de cacau na forma de "cabruca" predomina na paisagem da bacia, ocorrendo nas porções oeste, central e leste da área em estudo. Por sua vez, as áreas consideradas de adequabilidade favorável associam-se às regiões antropizadas por pastagens, cenários urbanos e solo exposto (Figura 15).

Já as APP consideradas como de adequabilidade restrita dão-se associadas aos topos de morro da porção oeste da bacia, áreas de encosta com declividades

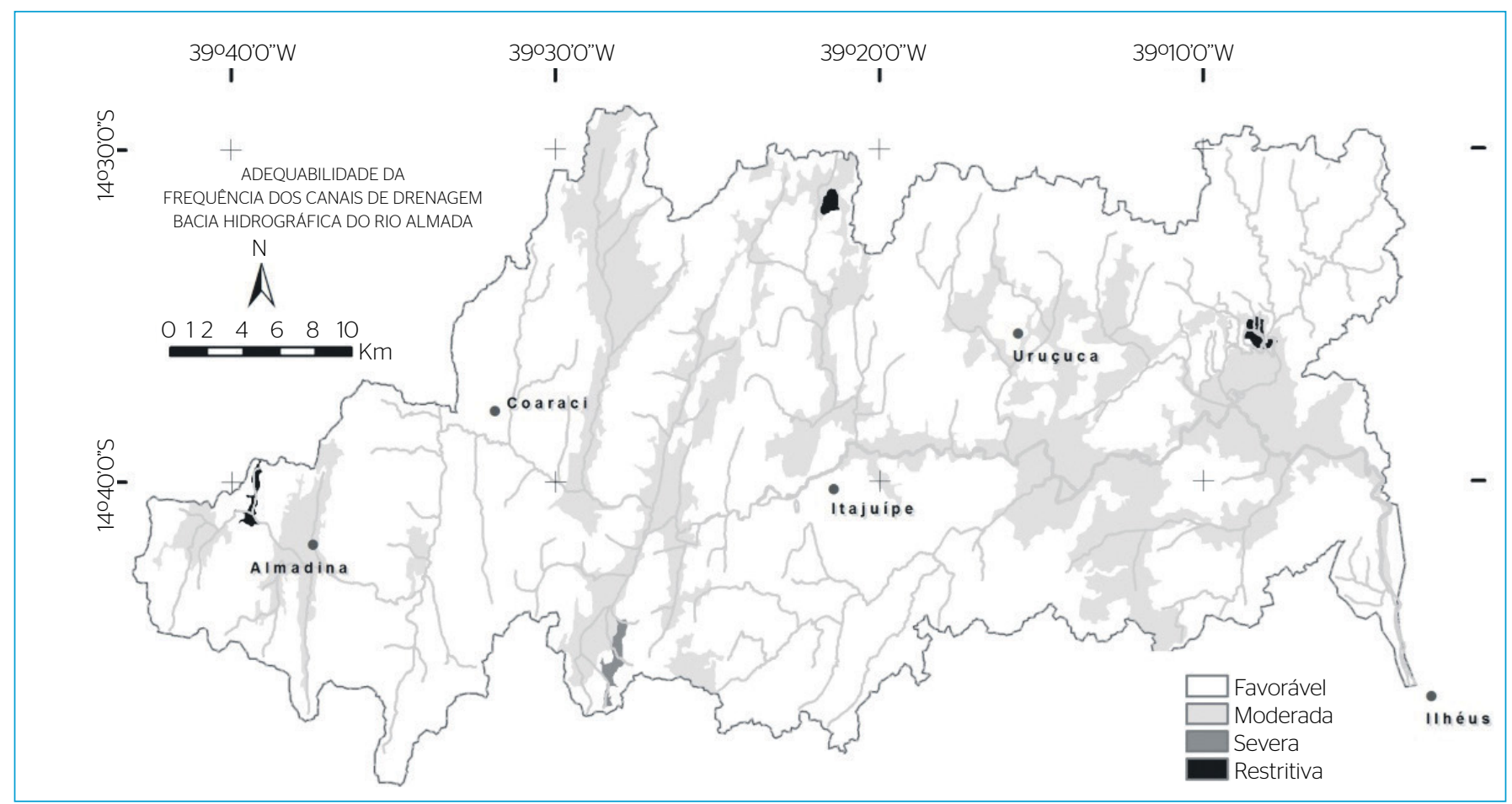

Figura 13 - Distribuição da adequabilidade à frequência dos canais de drenagem na área da Bacia Hidrográfica do Rio Almada.

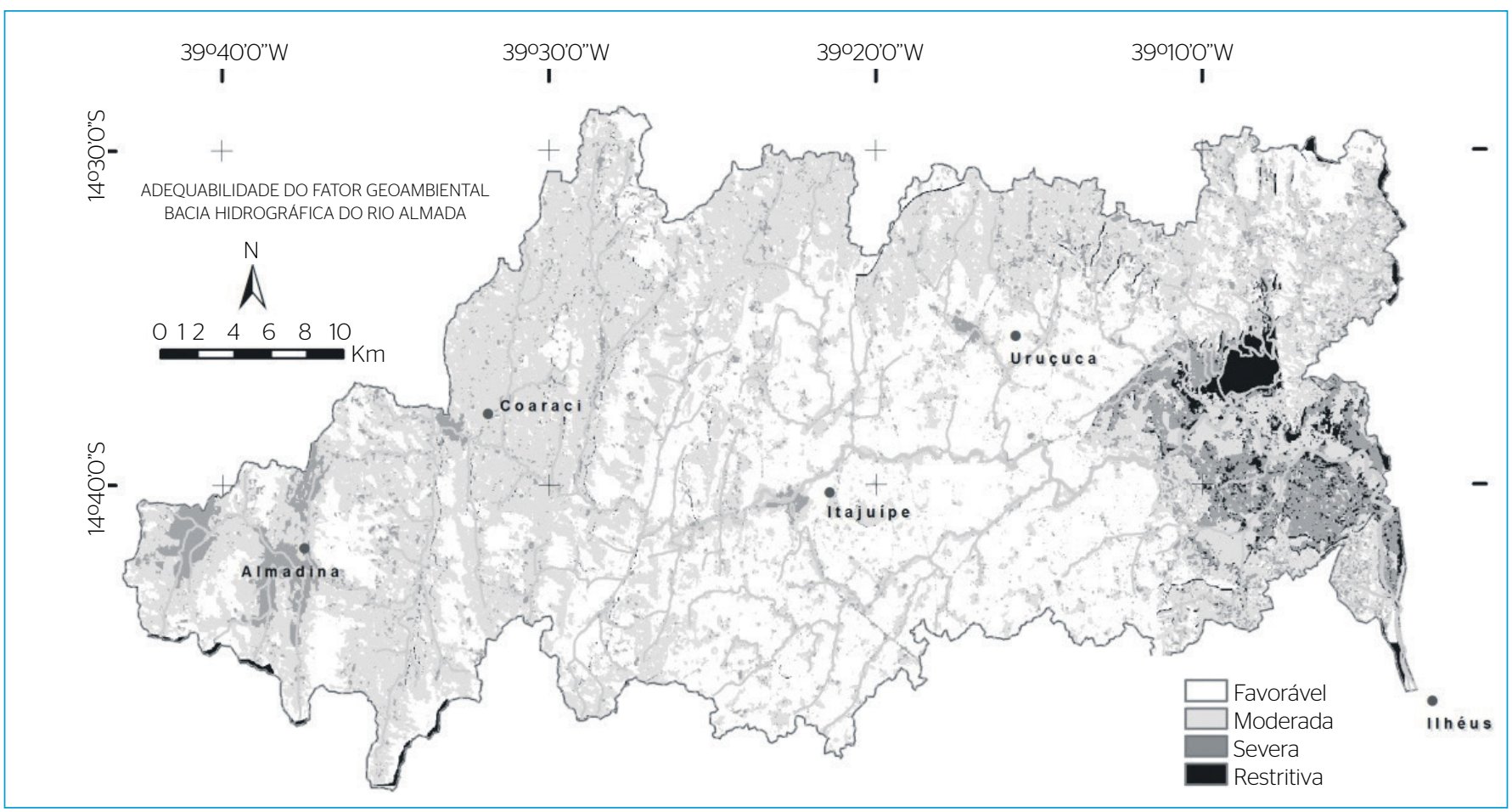

Figura 14 - Distribuição das adequabilidades do fator geoambiental na área da Bacia Hidrográfica do Rio Almada. 
superiores a 100\%, margens de cursos d'água, áreas úmidas e nascentes, conforme disposto no Código Florestal Brasileiro (BRASIL, 2012) (Figura 16).

Por fim, a Figura 17 apresenta a adequabilidade para a disposição ambiental de rejeitos na BHRA obtida da interação das adequabilidades dos fatores geotécnico, geomorfológico, geoambiental e de uso e ocupação do solo, conforme a álgebra de mapas definida na Equação 1. De acordo com a Figura 17, os resultados encontrados atestam o cenário em que a área da BHRA apresenta

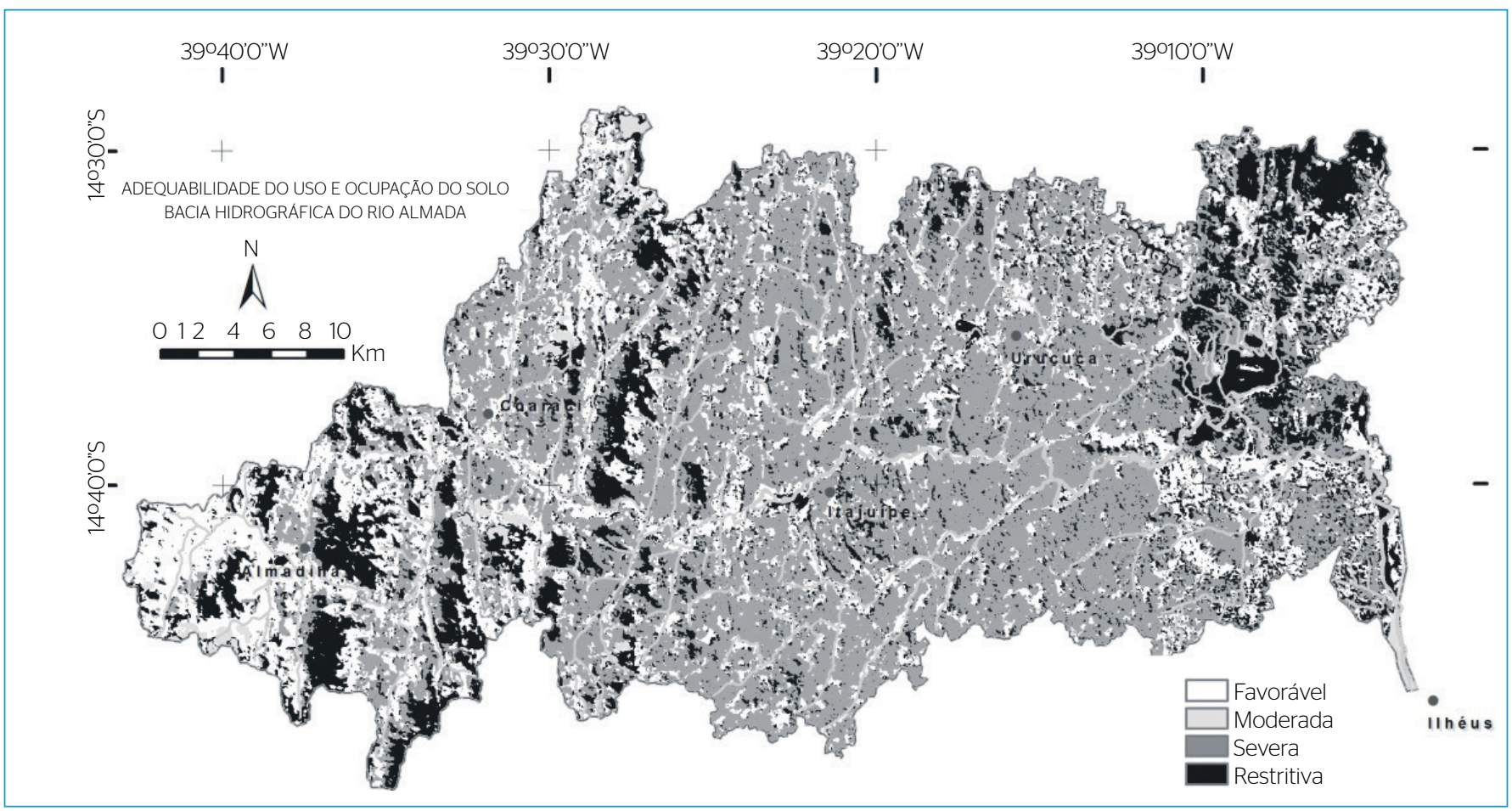

Figura 15 - Distribuição das adequabilidades ao uso e à ocupação do solo na área da Bacia Hidrográfica Do Rio Almada.

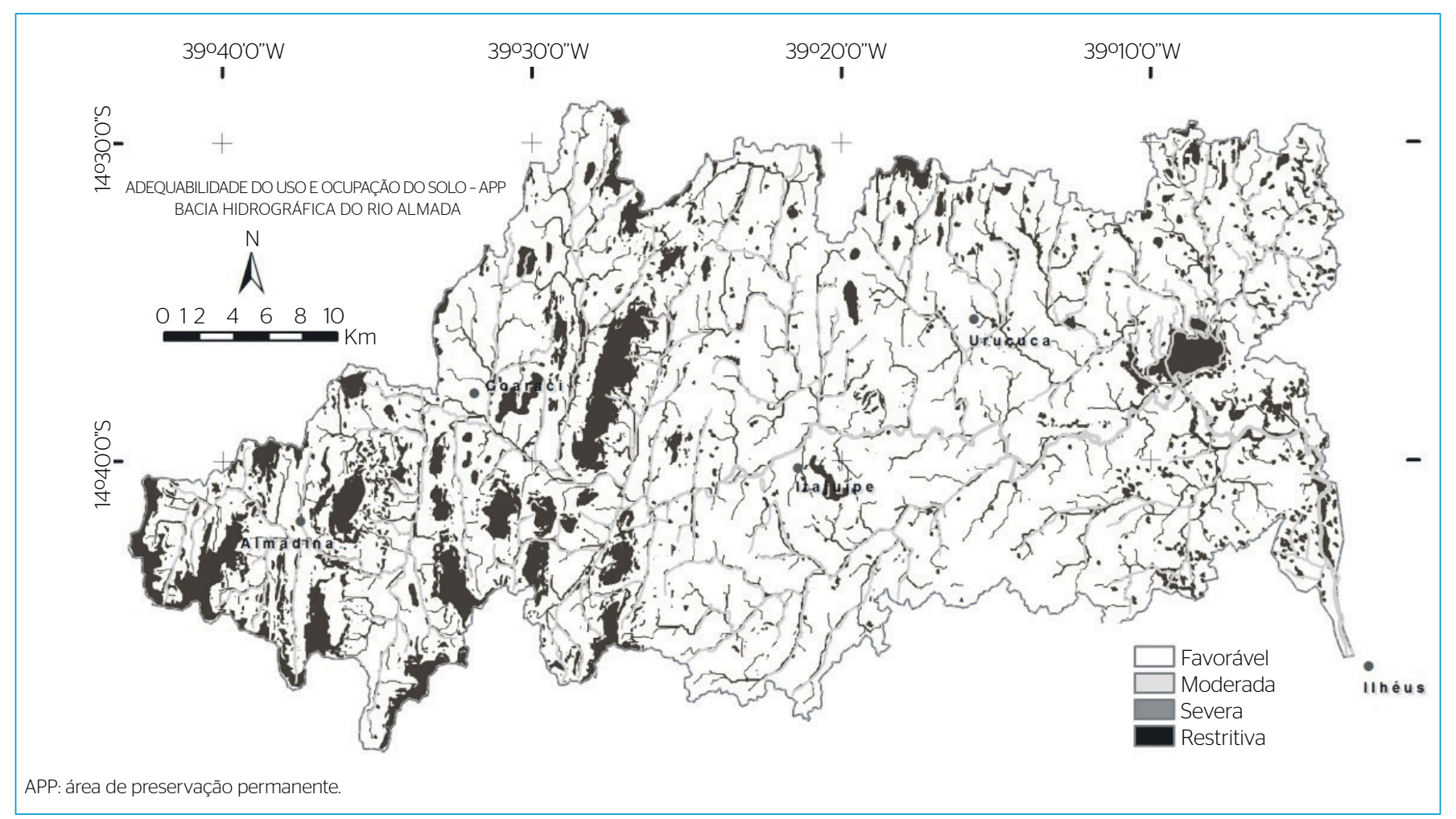

Figura 16 - Distribuição das restrições de área de preservação permanente na Bacia Hidrográfica do Rio Almada. 


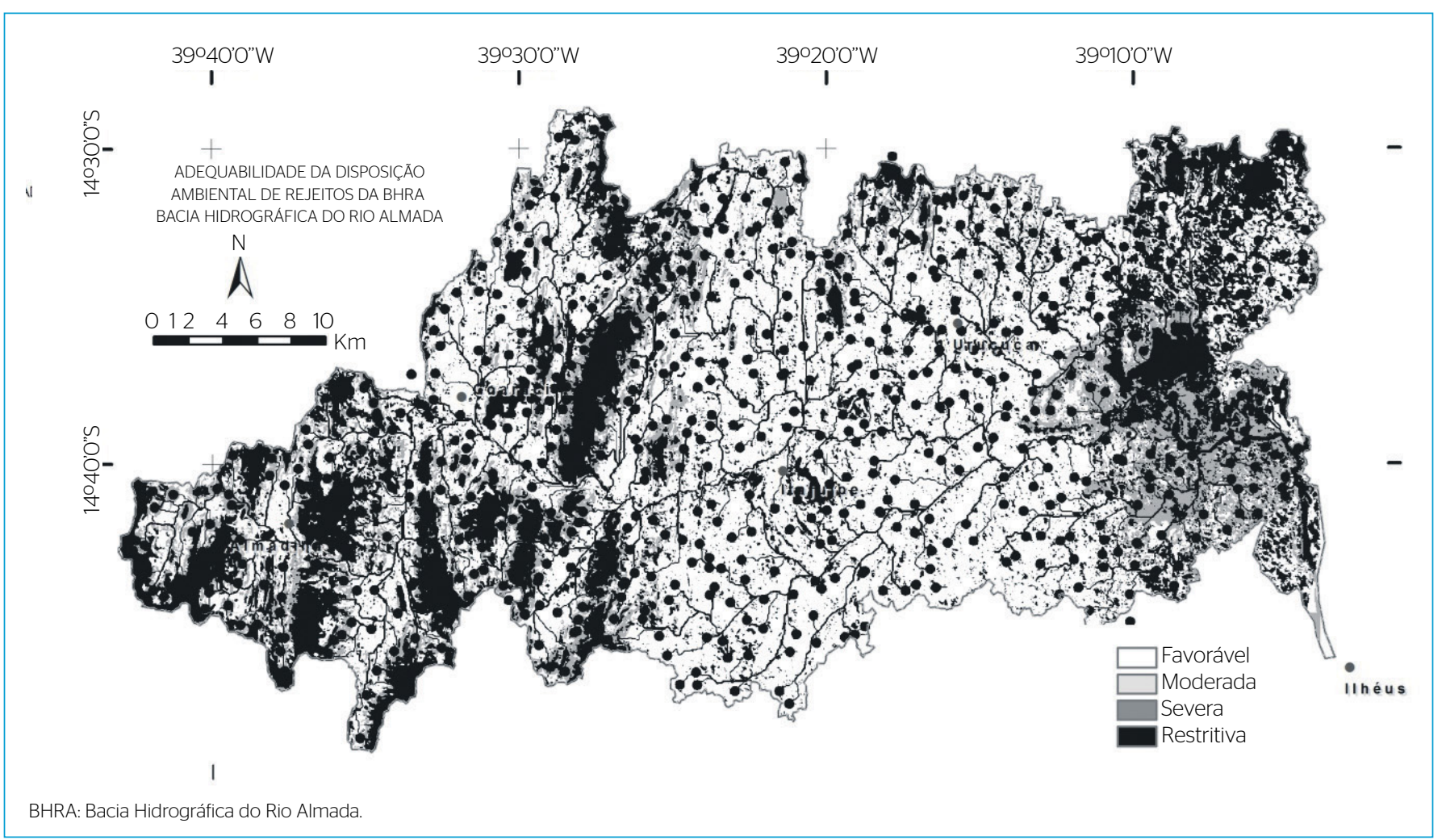

Figura 17 - Distribuição da adequabilidade da disposição ambiental de rejeitos na Bacia Hidrográfica do Rio Almada

mais concentração de adequabilidades severas e restritivas localizadas nas porções oeste, norte e leste.

A porção oeste da bacia, mais precisamente a partir da cidade de Itajuípe, possui suas restrições vinculadas à extensa ocorrência de APPs em áreas com declividade superior a $45^{\circ}$ e em porções de topo de morro, regiões associadas à presença de floresta densa. A porção leste, por sua vez, tem a sua adequabilidade severa controlada pela extensa ocorrência de sedimentos arenosos não consolidados, aliada à presença de nível freático raso e espodossolo. É relevante, ainda nessa porção da bacia, a ocorrência de APPs associadas a áreas úmidas e manguezais, além da presença de bolsões de floresta preservada, a exemplo da encontrada na porção nordeste de uma área do Parque Estadual da Serra do Conduru.

\section{CONCLUSÕES}

Conforme exposto, o método adotado parte do princípio de que cada um dos atributos físico-ambientais avaliados possui características que podem ser adequadas ou não para a implantação da intervenção de engenharia, nesse caso a implantação de aterros sanitários. Dessa maneira, quando analisados em conjunto, esses atributos refletem a aptidão ao uso específico de determinada unidade de área.
Em razão da escala de trabalho adotada, de caráter regional, a utilização do produto cartográfico final remete-se à interpretação de caráter orientativo, em virtude das limitações inerentes à acurácia da escala. Porém, mesmo com o conhecimento sobre a bacia em um cenário regional, é possível delinear compartimentos distintos associados às características de substrato rochoso e de formas de relevo, a exemplo da ocorrência de áreas inadequadas por conta do substrato arenoso da planície costeira e do relevo de morros e serras da porção oeste da bacia.

Com relação ao atributo de uso e ocupação do solo, os dados de mapeamento, obtidos da interpretação de imagens de satélite, com resolução de pixel de $30 \times 30 \mathrm{~m}$, conferem compatibilidade à escala regional de 1:100.000 adotada, resultando em conhecimento satisfatório sobre as tipologias de uso e ocupação do solo, úteis na definição das adequabilidades da área, em virtude da ocorrência de áreas degradadas por pastagens e solo expostos favoráveis à implantação do empreendimento.

Por fim, salienta-se que o estudo ora proposto não objetivou propriamente a delimitação de uma gleba ou um polígono para implantação da intervenção, e sim visou apresentar o panorama da adequabilidade da bacia diante da implantação de áreas para disposição ambiental de rejeitos. 


\section{REFERÊNCIAS}

AFZALI, A.; SABRI, S.; RASHID, M.; SAMANI, J.M.V.; LUDIN, A.N.M. (2014) Inter-municipal landfill site selection using analytic network process. Water Resources Management, v. 28, n. 8, p. 2179-2194.

ARAÚJO, P.C.; RIEDEL, P.S.; BROLLO, M.J.; VEDOVELLO, R. (1999) Aplicação do método multi-critério em sistemas de informações geográficas na escolha de locais para a disposição de resíduos sólidos no município de Americana-SP In: Congresso Brasileiro de Geologia de Engenharia, 9. Anais... São Pedro: ABGE. p. 13, v. 1.

ARCANJO, J.B.A. (1997) Programa Levantamentos Geológicos Básicos do Brasil. Itabuna. Folha Sd.24-Y-B-Vi. Estado da Bahia Escala 1:100.000. Brasília: CPRM. 276 p.

BAHRANI, S.; EBADI, T.; EHSANI, H.; YOUSEFI, H.; MAKNOON, R. (2016) Modeling landfill site selection by multi-criteria decision making and fuzzy functions in GIS, case study: Shabestar, Iran. Environmental Earth Sciences, v. 75, n. 4, p. 337.

BASILIO, J.A.F.; GANDOLFI, N.; ZUQUETTE, L.V.(2001) Procedimentos para a hierarquização de áreas para aterros sanitários a partir de resultados de mapeamentos geotécnicos: aplicação na região de Campinas, SP. In: Simpósio Brasileiro de Cartografia Geotécnica, 4. Anais... Brasília: ABGE. p. 9, v. 1.

BESKESE, A.; DEMIR, H.H.; OZCAN, H.K.; OKTEN, H.E. (2O15) Landfill site selection using fuzzy AHP and fuzzy TOPSIS: a case study for Istanbul. Environmental Earth Sciences, v. 73, n. 7, p. 3513-3521.

BRASIL. (2010) Lei n. ${ }^{1}$ 12.305, de 2 de agosto de 2010. Institui a Política Nacional de Resíduos Sólidos, altera a Lei n.0 9.605, de 12 de fevereiro de 1998 e dá outras providências. Diário Oficial da União. Disponível em: <http://www.planalto.gov.br/ccivil_03/_ato20072010/2010/lei//12305.htm>. Acesso em: 15 mar. 2016.

BRASIL. (2012) Lei n.o 12.651, de 25 de maio de 2012. Dispõe sobre a proteção da vegetação nativa e dá outras providências. Diário Oficial da União. Disponível em: <http://www.planalto.gov. br/ccivil_03/_ato2011-2014/2012/lei/l12651.htm>. Acesso em: 8 jun. 2016.

BROLLO, M.J.; VEDOVELLO, R.; SILVA, P.C.F.; HOLL, M.C.; GUTJHAR, M.R.; IRITANI, M.A. (1998) Seleção preliminar de áreas para disposição de resíduos na Região Metropolitana de Campinas, SP. In: Simpósio Brasileiro de Cartografia Geotécnica, 3. Anais... Florianópolis: ABGE. p. 13, v. 1.

CALIJURI, M.L.; MELO, A.L.O.; LORENTZ, J.F. (2002) Identificação de áreas para implantação de aterros sanitários com uso de análise estratégica de decisão. Informática Pública, v. 4, n. 2, p. 231-250.

COSTA, T.C.D.; GANDOLFI, N.; COSTA, J.A. (2002) Carta de áreas preferenciais a instalação de aterro sanitário na região metropolitana de Belém, na escala 1:50.000. In: Congresso Brasileiro de Geologia de Engenharia e Ambiental, 10. Anais... Ouro Preto: ABGE. p. 15, v. 1.
CUNHA, M.A. \& PARZANESE, G.A.C. (1993) Proposta metodológica para a definição de critérios geológico-geotécnicos para a escolha de locais de disposição de resíduos industriais. In: Congresso Brasileiro de Geologia de Engenharia, 7. Anais... São Paulo: ABGE. p. 161-167.

DONEVSKA, K.R.; GORSEVSKI, P.V.; JOVANOVSKI, M.; PESEVSKI, I. (2012) Regional non-hazardous landfill site selection by integrating fuzzy logic, AHP and geographic information systems. Environmental Earth Sciences, v. 67, n. 1, p. 121-131.

ERSOY, H. \& BULUT, F. (2009) Spatial and multi-criteria decision analysis-based methodology for landfill site selection in growing urban regions. Waste Management \& Research, v. 27, n. 5, p. 489-500.

ESKANDARI, M.; HOMAEE, M.; MAHMODI, S. (2012) An integrated multi criteria approach for landfill siting in a conflicting environmental, economical and socio-cultural area. Waste Management, v. 32, n. 8, p.1528-1538.

FRANCO, G.B. (2010) Diagnóstico da fragilidade ambiental e da qualidade da água da bacia do rio Almada, Bahia. 206 f. Tese (Doutorado em Engenharia Civil) - Universidade Federal de Viçosa, Viçosa, MG

GOMES, R.L. (2013) Avaliação da fragilidade ambiental e vulnerabilidade natural à perda de solo da bacia hidrográfica do rio Almada. Boletim de Geografia, v. 31, n. 3, p. 41-53.

GOMES, R.L. (2016) Elaboração da carta de adequabilidade para disposição ambiental de rejeitos na Bacia Hidrográfica do Rio Almada-BA. Relatório de Projeto de Pesquisa - Universidade Estadual de Santa Cruz. Projeto: 220.1000.1391, 95 p.

GOMES, R.L.; MORAES, M.E.B.; MOREAU, A.M.S.; MOREAU, M.S.; FRANCO, G.B.; MARQUES, E.A.G. (2012) Aspectos físico-ambientais e de uso e ocupação do solo da bacia hidrográfica do Rio AlmadaBA. Boletim de Geografia, v. 30, n. 2, p. 45-57.

GOMES, R.L.; VALADARES, J.O.; MORAES, M.E.B.; FRANCO, G.B.; MARQUES, E.A.G. (2013) Panorama do uso e ocupação do solo presente nas áreas de preservação permanente da bacia hidrográfica do Rio Almada-BA. Revista de Geografia (UFPE), v. 30, n. 3, p. 98-115.

INSTITUTO NACIONAL DE PESQUISAS ESPACIAIS - INPE. (2008) TOPODATA: guia para utilização de dados geomorfológicos locais. INPE: São José dos Campos. Disponível em: <http://mtc-m18. sid.inpe.br/col/sid.inpe.br/mtcm18@80/2008/07.11.19.24/doc/ publicacao.pdf>. Acesso em: 15 ago. 2013.

ISALOU, A.A.; ZAMANI, V.; SHAHMORADI, B.; ALIZADEH, H. (2O13) Landfill site selection using integrated fuzzy logic and analytic network process (F-ANP). Environmental Earth Sciences, v. 68, n. 6. p. 1745-1755. 
KHAN, D. \& SAMADDER, S.R. (2014) Municipal solid waste management using Geographical Information System aided methods: a mini review. Waste Management \& Research, v. 32, n. 11, p. 1049-1062.

LANGER, M. (1995) Engineering geology and waste disposal: scientific report and recommendations of the International Association of Engineering Geology Commission No 14. Bulletin of the International Association of Engineering Geology, v. 51, n. 1, p. 5-29.

MARQUES, G.N. \& ZUQUETTE, L.V. (2004) Aplicação da técnica AHP para seleção de áreas para aterros sanitários - Região de Araraquara (SP), Brasil. In: Simpósio Brasileiro de Cartografia Geotécnica e Geoambiental, 5. Anais... São Carlos: SUPREMA. p. 10, v. 1.

MONTAÑO, M.; RANIERI, V.E.L:; SCHALCH, V:; FONTES, A.T;; CASTRO, M.C.A.A.SOUZA, M.P. (2O12) Integração de critérios técnicos, ambientais e sociais em estudos de alternativas locacionais para implantação de aterro sanitário. Engenharia Sanitária e Ambiental, 17(1), 61-70.

MURO, M.D. (2000) Carta de zoneamento para seleção de áreas frente à instalação de aterros sanitários no Município de São Carlos - SP: escala 1:50.000. Dissertação (Mestrado) - Universidade de São Paulo, São Carlos, SP.

NISHIYAMA, L.; MENEZES, D.B.; ZUQUETTE, L.V. (2004) Procedimentos de mapeamento geotécnico para indicação de áreas adequadas para aterro sanitário: aplicação no município de Uberlândia-MG. In: Simpósio Brasileiro de Cartografia Geotécnica e Geoambiental, 5. Anais... São Carlos: ABGE. p. 14, v. 1.

OHRI, A. \& SINGH, P.K. (2013) GIS based environmental decision support system for municipal landfill site selection. Management of Environmental Quality, v. 24, n. 583, p. 598.

PROSKE, H.; VLCKO, J.; ROSENBAUM, M.S.; DORN, M.; CULSHAW, M.; MARKER, B. (2005) Special purpose mapping for waste disposal sites. Report of IAEG Commission 1: Engineering Geological Maps. Bulletin of Engineering Geology and the Environment, v. 64, n. 1, p. 1-54.
REZAEIMAHMOUDI, M.; ESMAELI, A.; GHAREGOZLU, A.; SHABANIAN, H.; ROKNI, L. (2014) Application of geographical information system in disposal site selection for hazardous wastes. Journal of Environmental Health Science \& Engineering, v. 12, p. 141.

ROSS, J.L.S. (1994) Análise empírica da fragilidade dos ambientes naturais e antropizados. Revista do Departamento de Geografia, v. 8, p. 63-74.

ŞENER, B.; SÜZEN, M.L.; DOYURAN, V. (2006) Landfill site selection by using geographic information systems. Environmental Geology, v. 49, n. 3, p. 376-388.

SILVA, G.S. \& GOMES, R.L. (2010) Aplicação da técnica de avaliação do terreno e análise da fragilidade ambiental da bacia hidrográfica do Rio Almada. Caminhos de Geografia, v. 11, p. 240-259.

ZUQUETTE, L.V. (1987) Análise crítica da cartografia geotécnica e proposta metodológica para condições brasileiras. 219p. Tese (Doutorado em Geotecnia) - Escola de Engenharia de São Carlos, Universidade de São Paulo, São Carlos, SP.

ZUQUETTE, L.V. (1993) A importância do mapeamento geotécnico no uso e na ocupação do meio físico: fundamentos e guia para elaboração. 369p. v. 1. Tese (Livre Docência) - Escola de Engenharia de São Carlos, Universidade de São Paulo, São Carlos, SP.

ZUQUETTE, L.V. \& GANDOLFI, N. (1987) Mapeamento geotécnico aplicável a rejeitos sépticos. In: Congresso Brasileiro de Geologia de Engenharia, 5. Anais... São Paulo: EESC-USP. p. 313-321.

ZUQUETTE, L.V. \& GANDOLFI, N. (2004) Cartografia geotécnica. São Paulo: Oficina de Textos.

ZUQUETTE, L.V.; PEJON, O.J., SINELLI, O. (1994) Methodology of specific engineering geological mapping for selection of sites for waste disposal. In: Congress of the International Association of Engineering Geology, 7. Proceedings... Lisbon: FEUP. p. 2481-2489. 